\title{
Fossil Giraffidae (Mammalia, Artiodactyla) from the late Miocene of Thermopigi (Macedonia, Greece)
}

\author{
Alexandros Xafis, Evangelia Tsoukala, Nikos Solounias, Oleg Mandic, \\ Mathias Harzhauser, Friðgeir Grímsson, and Doris Nagel
}

\begin{abstract}
Palaeontologists have known about the fossiliferous site at Thermopigi (Central Macedonia, N. Greece) for the past two decades. Following the first field campaigns a wealth of new information on the overall geology, taphonomy and palaeontology of the site became available. With more than 1300 fossils, representing at least 20 mammalian species, Thermopigi is considered a rich late Miocene locality, with hipparions, bovids, giraffes and rhinos being the most prominent elements of the palaeofauna. Four different giraffids are identified: Helladotherium duvernoyi, Samotherium major, Palaeotragus rouenii, and a slightly larger Palaeotragus sp. The faunal assemblage reveals the northernmost occurrence of Samotherium major and the third recorded presence of this species from continental Greece. Helladotherium duvernoyi is the most abundant giraffid at Thermopigi, with the largest fossil collection containing both dental and skeletal elements. The comparison of Palaeotragus with other palaeotragine giraffids suggests the coexistence of two Palaeotragus taxa. The abundance of $H$. duvernoyi, the presence of $S$. major and the coexistence of the latter with P. rouenii and another slightly larger palaeotragine, indicate that the faunal assemblage at Thermopigi is of middle Turolian age, placing it in the MN12 zone.
\end{abstract}

Alexandros Xafis. Department of Paleontology, Faculty of Earth Sciences, University of Vienna, Vienna, Austria. alexandros.xafis@univie.ac.at

Evangelia Tsoukala. School of Geology, Faculty of Science, Aristotle University, Thessaloniki, Greece. lilits@geo.auth.gr

Nikos Solounias. Department of Anatomy, New York Institute of Technology College of Osteopathic Medicine, 8000 Northern Boulevard, Old Westbury, NY 11568, USA

Department of Paleontology, American Museum of Natural History, Central Park West at 79th Street, New York, NY 10024, USA. nsolouni@nyit.edu

Oleg Mandic. Geological-Palaeontological Department, Natural History Museum Vienna, Burgring 7, 1010

Xafis, Alexandros, Tsoukala, Evangelia, Solounias, Nikos, Mandic, Oleg, Harzhauser, Mathias, Grímsson, Friðgeir, and Nagel, Doris. 2019. Fossil Giraffidae (Mammalia, Artiodactyla) from the late-Miocene of Thermopigi (Macedonia, Greece). Palaeontologia Electronica 22.3.67 1-38. https://doi.org/10.26879/889 palaeo-electronica.org/content/2019/2784-giraffidae-of-thermopigi 
Vienna, Austria. oleg.mandic@nhm-wien.ac.at

Mathias Harzhauser. Geological-Palaeontological Department, Natural History Museum Vienna, Burgring

7, 1010 Vienna, Austria. mathias.harzhauser@nhm-wien.ac.at

Friðgeir Grímsson. Department of Botany and Biodiversity Research, University of Vienna, Austria.

fridgeir.grimsson@univie.ac.at

Doris Nagel. Department of Paleontology, Faculty of Earth Sciences, University of Vienna, Vienna, Austria.

doris.nagel@univie.ac.at

Keywords: giraffids; Helladotherium; Palaeotragus; Samotherium; Strymon Basin; Turolian

Submission: 15 May 2018. Acceptance: 4 October 2019.

\section{INTRODUCTION}

The Giraffomorpha constitutes a clade, which contains members of the Palaeomerycidae and Giraffidae (Sánchez et al., 2015). Giraffids are ruminant artiodactyls, outlined by the presence of a bilobed canine, absent upper and lower first premolars, brachydont and selenodont cheek teeth and long metapodials (Janis and Scott, 1987; Harris et al., 2010). Additionally, they exhibit epiphyseal cranial appendages, which are called ossicones (Janis, 1987; Solounias, 1988, 2007; Grossman and Solounias, 2014). The superfamily Giraffoidea used to include two families: a) Climacoceratidae (Hamilton, 1978), which is known from the late Miocene of Eastern and Southern Africa and b) Giraffidae (Gray, 1821), with the earliest forms recorded from the early Miocene of Libya (Arambourg, 1963; Mitchell and Skinner 2003; Solounias 2007; Harris et al., 2010). However, a recent study by Sánchez et al. (2015) has shown that Giraffoidea, together with Giraffa are included within the Giraffomorpha. Moreover, the most recent phylogenetic analysis grouped Giraffidae into three distinct clades: 1) a basal clade with Canthumeryx sirtensis Hamilton (1973), and Georgiomeryx georgalasi Paraskevaidis (1940), 2) stem giraffids including Injanatherium Heintz et al. (1981), and Giraffokeryx Pilgrim (1910) and 3) crown giraffids that comprise the largest number of taxa (Ríos et al., 2017).

Giraffids show a wide geographic distribution in Eurasia and Africa from the early Miocene, when ancestral forms of giraffes appear (Arambourg, 1963; Mitchell and Skinner, 2003; Harris et al., 2010; Solounias, 2007). In Greece, the family occurs from the middle Miocene of Chios, represented by Georgiomeryx georgalasi, until the early Pleistocene with the appearance of Palaeotragus inexspectatus Samson and Radulesco (1966), exhibiting a great diversification during the late Miocene (Melentis, 1974; Geraads, 1978; Kost- opoulos, 1996; Kostopoulos et al., 1996; Bonis et al., 1997; Gentry et al., 1999; Bonis and Bouvrain, 2003; Kostopoulos and Koufos, 2006; Kostopoulos, 2009; Athanassiou, 2014).

Thermopigi (SIT) is a newly reported late Miocene fossil mammal locality, situated within the municipality of Sintiki, which is located in Northern Greece and occupies the NE part of the Greek geographic region of Macedonia. Systematic excavations have been carried out in the area since 1999, under the leadership and supervision of one of the authors (ET). The research is ongoing under a long-term cooperation between AUTH, DGUS and PIUW.

Here we systematically describe and classify all available dental and postcranial fossil specimens belonging to Giraffidae from Thermopigi. Additionally, we target to enrich the faunal list of Thermopigi, following the work of Geraads et al. (2007). Moreover, we present the first reliable stratigraphic data covering the fossiliferous section at SIT. Ultimately, based on the giraffid assemblage, the biochronological position of Thermopigi is established for the first time.

\section{Geological Setting and Stratigraphy}

The fossiliferous site at Thermopigi ( $\left.41^{\circ} 17^{\prime} 16^{\prime \prime} \mathrm{N} 23^{\circ} 21^{\prime} 51^{\prime \prime} \mathrm{E}\right)$ is located $7 \mathrm{~km}$ from Sidirokastro and approximately $2.2 \mathrm{~km} \mathrm{~N}$ from the village of Thermopigi (Figure 1). The outcrop can be found on the eastern slope of a small stream, approximately $20 \mathrm{~m}$ from the bottom of a gorge, on the right side of a farmer's road. Geologically, the fossiliferous site consists of Neogene sediments that belong to the Strymon basin; a large NW-SE trending Neogene-Quaternary basin that parallels the Strymon river in SW Bulgaria and northern Greece (Tranos et al., 2008, 2011). In northern Greece, the basin interrupts the mountainous terrain and obscures at the largest part the tectonic contact, namely 'Strymonlinie' between the Serbo- 


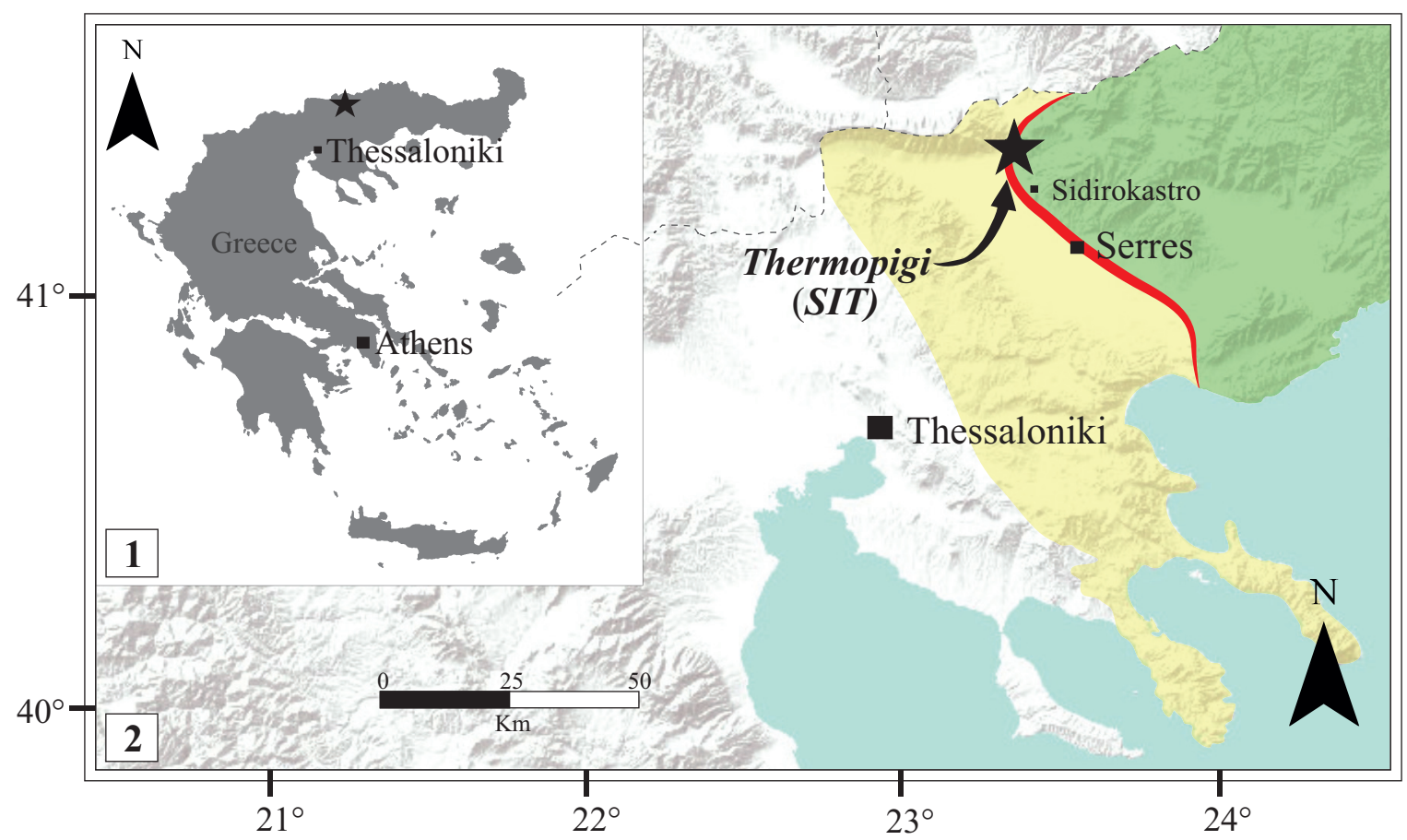

FIGURE 1. Map showing the geographic position of the study area. 1, The position of Thermopigi on the Greek map (indicated by the star). 2, Topographic map of northern Greece showing the position of the study area (indicated by the star). The yellow-highlighted area signifies the Serbomacedonian Massif. The green-highlighted area encloses the Rhodope Massif. The red line represents the border between the two Massifs (Strymonlinie). The dashed lines represent national borders. Scale equals $50 \mathrm{~km}$.

macedonian massif in the west and the Rhodope massif in the east (Kockel and Walther, 1965) (Figure 1.2). The Strymon basin consists of NeogeneQuaternary lacustrine and fluvial sedimentary deposits (Psilovikos and Karystineos, 1986) and was subjected to several deformational events (Tranos, 2011). The post-alpine sediments of the Strymon basin surrounding the excavation area have a thickness of approximately $4000 \mathrm{~m}$ and bear the marks of geothermal activity (Syrides and Koliadimou, 1994; Karydakis et al., 2005). At Thermopigi, only one fossiliferous site has been discovered so far and was named accordingly (SIT: Sidirokastro-Thermopigi). Some brief prospecting around the excavation site have not yielded any new fossil vertebrate-bearing sediments.

The Thermopigi section comprises an up to 35-m-thick succession of poorly exposed fluvial sand and gravel with intercalations of pedogenetically altered reddish to pinkish silt with frequent caliche nodules. Herein, we focus on the fossiliferous middle part of the section (Figure 2), which is bound by two unconformities from the lower and upper part.
This part of the section starts with c. $5 \mathrm{~m}$ of yellowish-grey, moderately sorted fine to medium sand with thin gravel intercalations (units 1 and 2 in Figure 2), overlain by c. $50 \mathrm{~cm}$ of poorly sorted, pinkish-brown, sandy siltstone. A 20-cm-thick layer of strongly lithified, yellowish-grey, medium to coarse sandstone forms the base of the fossiliferous bed (unit 4 in Figure 2), comprising $20 \mathrm{~cm}$ of reddish brown, micaceous, sandy siltstone with numerous vertebrate remains investigated by the present study. Up section follows $20 \mathrm{~cm}$ of pedogenically altered, olive-grey, well-sorted, medium sandstone (unit 6) and $50 \mathrm{~cm}$ of brick red claystone grading into pinkish grey and mottled sandy siltstone with scattered coarse sand grains (units 7-8). Units 9-10 form a 130-m-thick coarsening upward bed of light greenish grey, fine to medium sandstone passing into moderately sorted coarse gravel, pedogenically altered at the top. Seventyfive $\mathrm{cm}$ of homogenous brick red claystone forms unit 11 , which is overlain by a $65-\mathrm{cm}$-thick package of cross-bedded conglomerate, forming a fining upward sequence. The conglomerate is poorly sorted, with angular to subangular components of up to $3 \mathrm{~cm}$ in diameter. This conglomerate unit is 


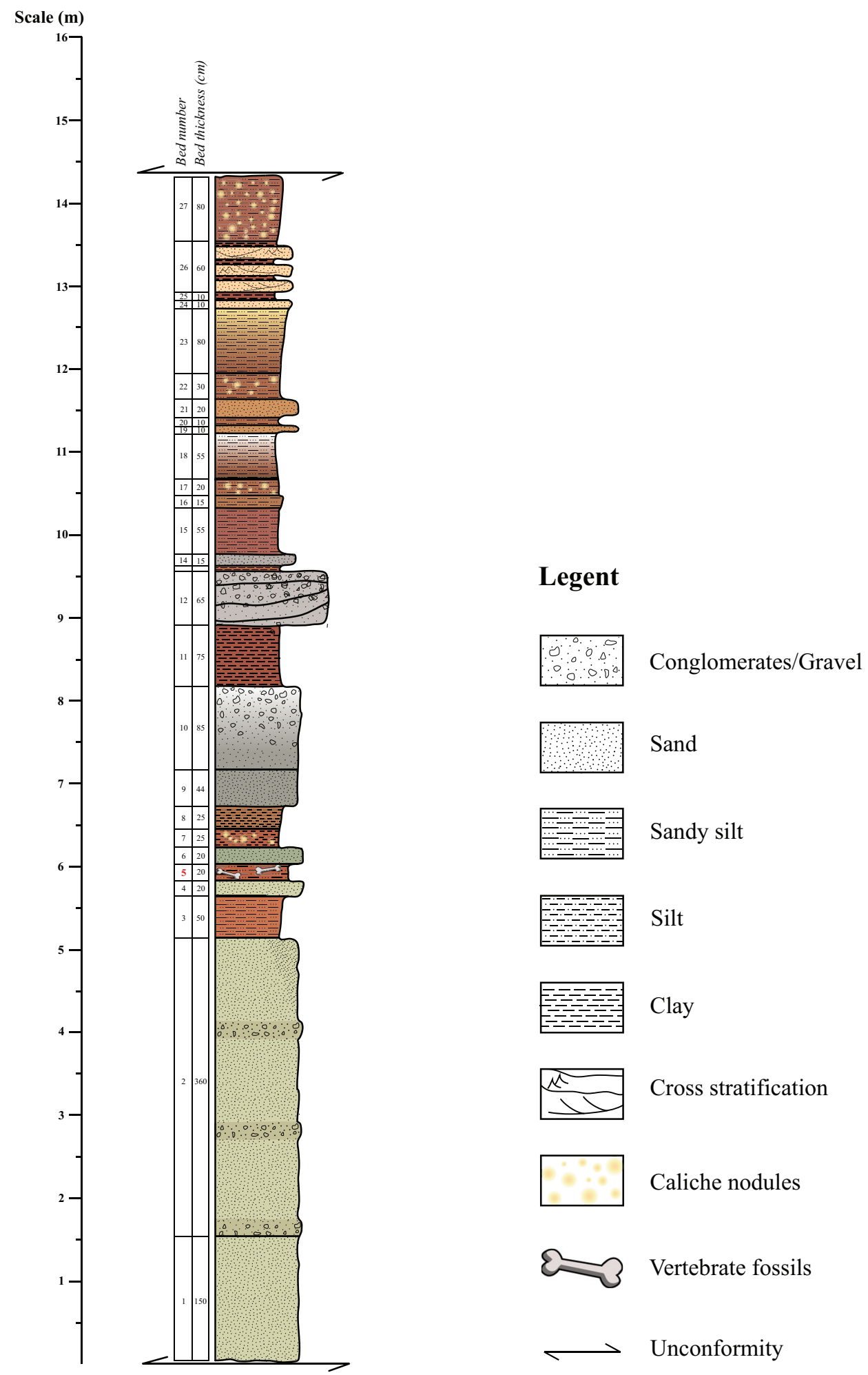

FIGURE 2. Stratigraphic log of Thermopigi. The fossiliferous layer is indicated by the red number (Bed number 5). For identification see the symbol legend. 
one of the few marker beds, which can be traced easily in the field. Units 13 to 18 comprise mainly brick red, partly mottled, micaceous silty claystone with a 15-cm-thick intercalation of a layer of strongly pedogenically altered, fine to coarse conglomerate (unit 14). Units 19 to 23 comprise 150 $\mathrm{cm}$ of brick red to pinkish, often mottled, clayey siltstone and silty fine sandstone, representing a coarsening upward sequence. Units 24 to 26 form an $80-\mathrm{cm}$-thick succession of four thin layers of cross-bedded, fine to medium sandstone intercalated in brick-red, strongly mottled claystone with traces of fossil roots. The top unit is formed by 80 $\mathrm{cm}$ of strongly mottled, pinkish, sandy siltstone with traces of roots.

\section{MATERIALS AND METHODS}

The fossil material from SIT is stored in the Municipal palaeontological exhibition of Thermopigi. The material was measured using an electronic caliper and measuring tape, for the larger specimens. Measurements are given in millimeters (mm) (see Appendices 1-3). All width measurements of dental elements were taken at the base of the crown. Morphological and metrical comparison was established by measuring material from several museums and institutes, as well as compiling data from the literature. Statistical analyses were achieved using the software PAST (Hammer et al., 2001). The nomenclature for cusps and crests of dental material follows the terminological framework by Bärmann and Rössner (2011). Anatomical terms used for description of postcranial material follow Schaller (2007).

\section{Institutional Abbreviations}

AUTH: Aristotle University of Thessaloniki, Greece; DGUS: Department of Geology, University of Sofia, Bulgaria; NHMW: Naturhistorisches Museum Wien, Vienna, Austria; PIUW: Paläontologisches Institut der Universität Wien, Vienna, Austria; MNHN: Muséum national d'Histoire naturelle, Paris, France.

\section{Anatomical Abbreviations}

D2/d2: upper/lower second deciduous premolar; D3/d3: upper/lower third deciduous premolar; D4/ d4: upper/lower fourth deciduous premolar; P2/p2: upper/lower second premolar; P3/p3: upper/lower third premolar; P4/p4: upper/lower fourth premolar; M1/m1: upper/lower first molar; M2/m2: upper/ lower second molar; M3/m3: upper/lower third molar; d: deciduous premolar

\section{SYSTEMATIC PALAEONTOLOGY}

Class MAMMALIA Linnaeus, 1758

Order ARTIODACTYLA Owen, 1848

Family GIRAFFIDAE Gray, 1821

Subfamily SIVATHERIINAE Zittel, 1893

Genus HELLADOTHERIUM Gaudry, 1860

Type species. Helladotherium duvernoyi Gaudry and Lartet, 1856

Helladotherium duvernoyi (Gaudry and Lartet, 1856) Figures 3-4

\section{Material}

Isolated left dP2 (SIT 1425), part of isolated right dP3 (SIT 1260), isolated left dP4 (SIT 671), part of right maxilla with P2-M2 (SIT 1254), isolated left P2 (SIT 1001), isolated left P3 (SIT 1251), isolated left P4 (SIT 651), isolated right $\mathrm{m} 1$ (SIT 1489), right scapula (SIT 1034), distal part of right humerus (SIT 318), distal part of right humerus (SIT 306), proximal part of left radius (SIT 319), left radius with parts of the ulna (SIT 937), right magnum-capitatum (SIT 542), right metacarpal (SIT 920), left metacarpal (SIT 300), left metacarpal (SIT 1254), left metacarpal (SIT 1043), distal part of right metacarpal (SIT 863), proximal part of left tibia (SIT 317), distal part of left tibia (SIT 316), distal part of right tibia (SIT 1255), left lateral malleolus (SIT 1002), left astragalus (SIT 1005), left astragalus (SIT 1109), left calcaneus (SIT 1004), left calcaneus (SIT 315), left cubonavicular (SIT 1059), right tarsus complex in block with: distal part of tibia, lateral malleolus, astragalus, calcaneus, cubonavicular and cuneiform (SIT 992), proximal part of right metatarsal (SIT 301), proximal part of left metatarsal (SIT 938), distal part of left metatarsal (SIT 921), right proximal phalanx (SIT 1250), right proximal phalanx (SIT 310), left proximal phalanx (SIT 311), right distal phalanx (SIT 541).

\section{Descriptions}

Helladotherium duvernoyi is the most abundant giraffid at SIT. The fossil collection includes dental and post-cranial elements revealing all the diagnostic characters of the species, as well as a notable intraspecific size variation.

Dentition. The cranial material of Helladotherium duvernoyi is limited to a part of the maxilla, some isolated premolars as well as three deciduous upper premolars. The dP2 (SIT 1425; Figure 3.1) is sub-triangular in occlusal view. The anterior cone is long, and the anterior fossa is narrow and ovalshaped. The protocone is small but more robust than the anterior lobe. Metaconule and metacone 

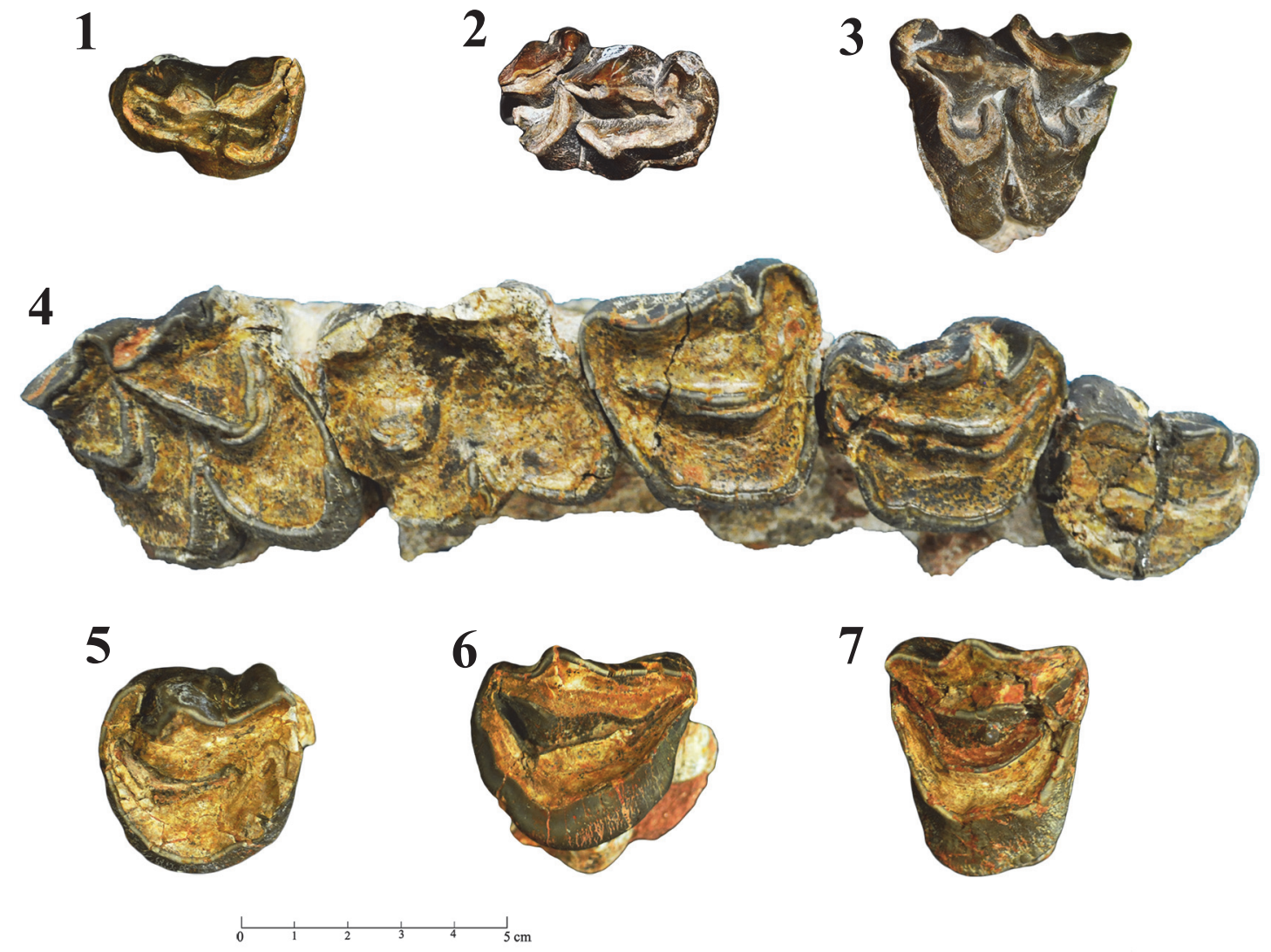

FIGURE 3. Fossil dental material of Helladotherium duvernoyi from Thermopigi: 1, SIT 1425, Isolated left dP2; 2, SIT 1260, part of isolated right dP3; 3, SIT 671, isolated left dP4; 4, SIT 1254, part of right maxilla with P2-M2; 5, SIT 1001, isolated left P2; 6, SIT 1251, isolated left P3; 7, SIT 651, isolated left P4. Scale equals $5 \mathrm{~cm}$.

are well developed, making the tooth wider distally and giving the triangular shape in occlusal view. The metastyle is blunt and thick, pointing labially. The paracone is robust, forming a sharp and strong labial pillar, which runs anteriorly until it meets the parastyle. A cingulum can be found on the base of the anterior crista of the anterior cone, which runs from the base of the parastyle until the enamel rim of the anterior tip of the anterior cone. The dP3 (SIT 1260; Figure 3.2) is partly preserved. The anterior cone is robust creating a strong labial pillar. On the bottom of the anterior crista of the anterior cone there is a small blunt style. The paracone is also strong but not as blunt as the anterior cone. The anterior fossa is wide and long. The mesostyle is well developed, and it is projected labially. Metacone and metaconule are both fairly developed. The dP4 (SIT 671; Figure 3.3) is big and fully molarized. The protocone is extended more lingually than the metaconule, but the latter is notably wider. The anterior cingulum is strong, creating a small stylid-like bump on the base of the external preprotocrista. The entostyle is also strong and pointy, with a secondary small and weak style, towards the metaconule. There are two metaconule folds, which are parallel to each other. The posterior cingulum is weak, but it runs until the medial level of the metastyle. All the labial styles are strong, with the parastyle being the most robust.

In specimen SIT1254 (Figure 3.4), estimation of the length of the complete toothrow is not possible, since the M3 is absent. In occlusal aspect, P2 has an almost semicircular shape. The anterior style is large, kidney-shaped and separated from the anterolabial cone with a strong folded anterolabial crista. The anterolabial cone is also strong and triangular. The distal part of the tooth reveals a weak posterolingual cone. The lingual cone is smooth and fairly developed, without additional cin- 

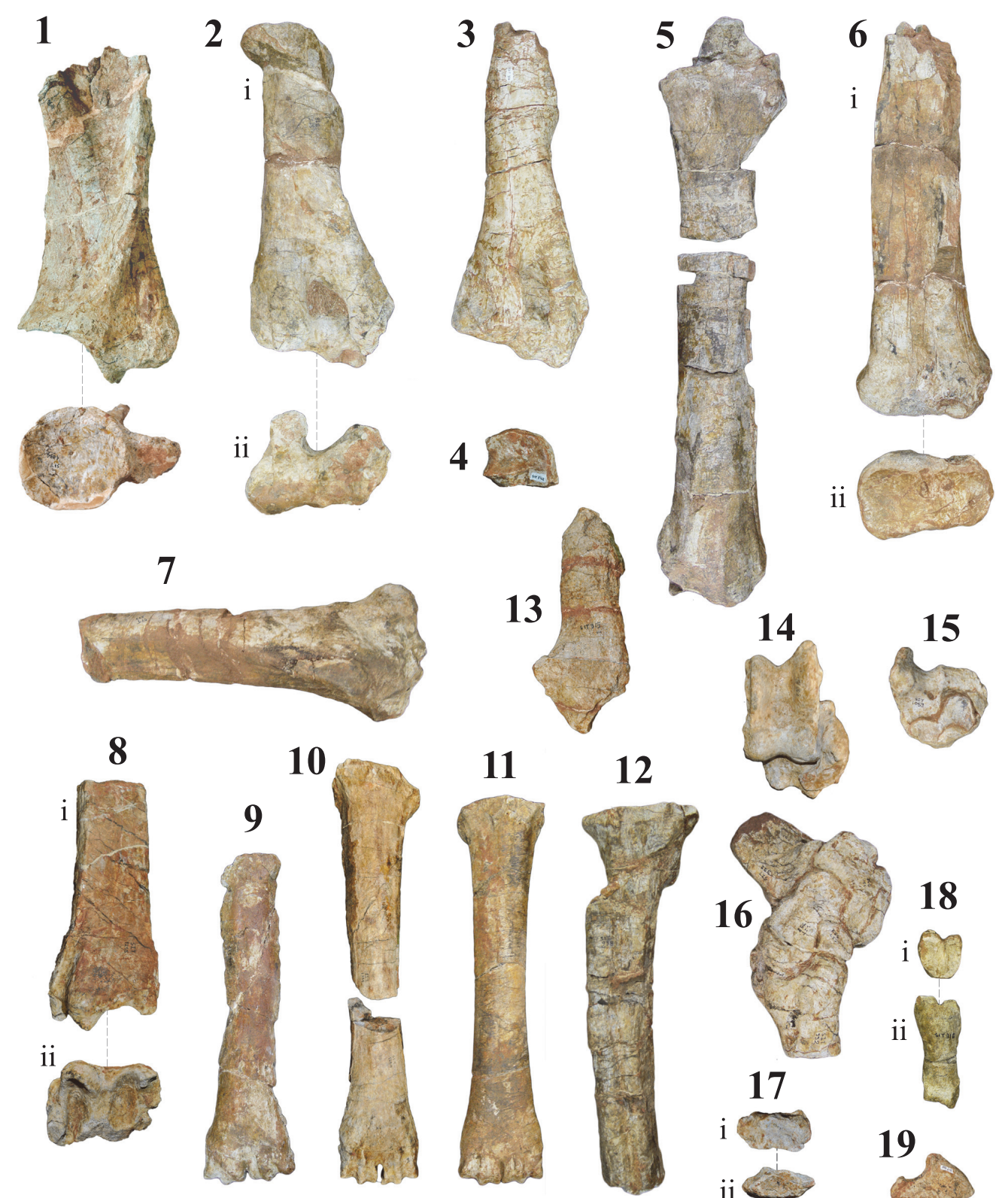

12

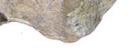

14
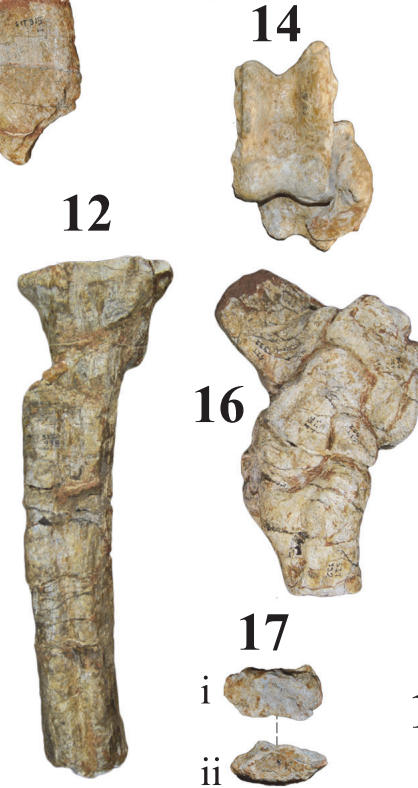

15
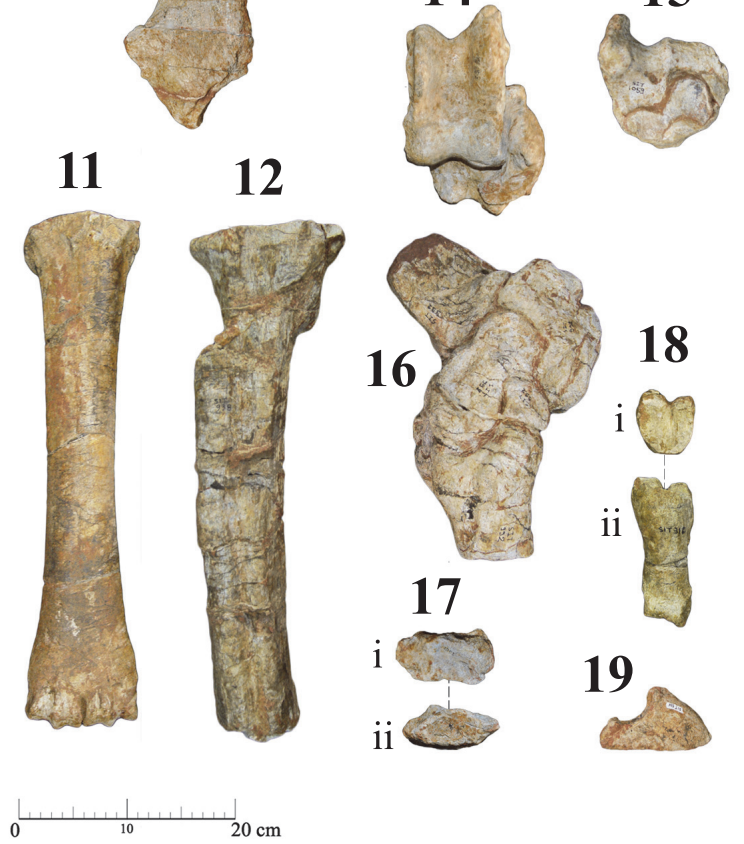

FIGURE 4. Fossil post-cranial material of Helladotherium duvernoyi from Thermopigi: 1, SIT 1034, right scapula, (i) lateral view and (ii) cranioventral view; 2, SIT 318, distal part of right humerus, (i) caudal view and (ii) distal view; 3 , SIT 306, distal part of right humerus; 4, SIT 524, right magnum-capitatum; 5, SIT 937, left radius with parts of the ulna; 6, SIT 319, proximal part of left radius, (i) caudal view and (ii) distal view; 7, SIT 317, proximal part of left tibia; 8, SIT 1255, distal part of right tibia, (i) cranial view and (ii) distal view; 9, SIT 300, left metacarpal (Mc III+IV); 10, SIT 1235, left metacarpal (Mc III+IV); 11, SIT 920, right metacarpal (Mc III+IV); 12, SIT 938, proximal part of left metatarsal (Mt III+IV); 13, SIT 315, left calcaneus; 14, SIT 1004-1005, complex with left calcaneus and astragalus; 15, SIT 1059, left cubonavicular; 16, SIT 922, right tarsus complex in block with: distal part of tibia, lateral malleolus, astragalus, calcaneus, cubonavicular and cuneiform (medial view); 17, SIT 1002, left lateral malleolus, (i) lateral view and (ii) distal view; 18, SIT 310, right first phalanx, (i) dorsal view and (ii) proximal view; 19, SIT 541, right third phalanx. Scale equals $20 \mathrm{~cm}$. 
gula. The fossa is narrow and simple, and the central fold is missing, probably due to the advanced wear stage. Lingually, the P3 shows a well-developed and relatively flattened anterolingual cone. The anterolabial cone is wider than the anterolingual cone, bearing a large anterior style. The posterolabial cone is thin. The P4 is rectangular in occlusal aspect, having a strong and prominent anterolingual cone. The posterolingual cone is not as well defined as in P3 but a small basal pillar can occur lingually. The anterolabial cone is wide creating a large area between the internal and external posterolabial crista. The anterior style is big, extending posteriorly as in P3. The posterolabial cone is much bigger than in P2 and P3, while the posterior style is not as prominent. Due to the high degree of wear, the occlusal morphology of the M1 is not preserved. However, the lingual cusps show a strong rotation pointing anteriorly. The protocone and metaconule seem to have the same size. The outline of $\mathrm{M} 2$ reveals a square shape. As in M1, the lingual cusps are also tilted anteriorly. The protocone is larger than the metaconule. The shape of the protocone is slightly triangular and pointy while the metaconule is semicircular. Paracone and metacone appear to have the same size and a distinct triangular shape. The mesostyle is very well developed and prominent. Between the two lobes a well-defined fosseta can be found. The fosseta is oval-shaped with the long axis almost perpendicular to the axis of the toothrow. A weak lingual cingulum can also be found between the two lobes, which is stronger on the side of the protocone.

The three isolated premolars (SIT 1001, SIT 1251 and SIT 651) appear to be worn in the same level, which would suggest that they could belong to the same individual. The lingual cone of the P2 (SIT 1001; Figure 3.5) is very well-pronounced, without basal pillars or cingula. The anterolingual crista is simple and rounded. The anterolabial cone is very well developed. The enamel rims at the end of the cone create a right angle, which forms a square like space between the anterolabial cone and the mesolabial crista. The P3 (SIT 1251; Figure 3.6) shows the same morphology as the one of SIT 1254. Since SIT 1251 is not as worn as SIT 1254 , the central fold can be observed. The fold is situated on the inner side of the posterolingual crista and it is S-shaped. The P4 (SIT 651; Figure 3.7) also shows the same morphology with the one of SIT 1254. Likewise, due to wear degree, SIT 651 reveals a rounded and robust fold. The fold is positioned on the inner side of the mesolabial crista, on the medial plane of the fossa. Lingually, the fold is pointy and obelisk-shaped.

SIT 1489 represents an isolated, right, almost completely unworn $\mathrm{m} 1$. The two lobes of the tooth are well separated labially. A deep valley is parting protoconid and hypoconid, running until the base of the crown, possibly keeping the cusps separated until a terminal wear stage. Both latter cusps are not particularly developed. The metaconid is larger than the entoconid, with a well-developed internal postmetacristid that covers a small part of the preentocristid, in lingual aspect. An anterior cingulum is presented, forming a small stylid.

Scapula. The scapula (SIT 1034; Figure 4.1) is very fragmented, and the dorsal margin is not preserved. In cranioventral aspect, the glenoid cavity shows a pentagonal outline. The lips of the glenoid cavity are sharp and well developed. In lateral aspect, the supraglenoid tuber is strong, forming an approximately $75^{\circ}$ angle with the scapular notch. The neck of the scapula is very developed forming a triangular protuberance, which supports the development of the spine. The spina scapulae is very thick, straight and extended cranially, forming a $23^{\circ}$ angle with the axis of the scapula, covering the fossa supraspinata completely. The fossa infraspinata is deep and triangular in the area of the attachment of the infraspinatus muscle. Caudally, in the area of attachment of the teres major and teres minor muscles, the caudal border of the fossa gets notably more robust probably leading to a strong caudal angle. Medially, the subscapular fossa is large and with a flat surface extending from the neck of the scapula to the dorsal limits of the specimen.

Humerus. Both humeri (SIT 306, SIT 318; Figure 4.2-3) maintain the distal epiphysis as well as a big part of the diaphysis. The tuberositas teres major is weak and long. The crest of the humerus is blunt but very well pronounced, probably leading to an equally blunt deltoid tuberosity. The radial fossa is relatively shallow, creating a small rounded concavity on the level between the groove of the medial and lateral trochleae and the keel of the lateral trochlea. This keel is wide and blunt, getting sharper as it runs caudally. The olecranon fossa is wide and sub-rounded in caudal aspect. The medial and lateral epicondyles are almost equally developed, with the latter being slightly stronger. The distal trochlea is almost symmetrical. In cranial aspect, the condyles are tilted towards the lateral epicondyle, and the groove between the two trochleae are forming an open obtuse angle. 
Radius. The head of the radius (SIT 319, SIT 937; Figure 4.5-6) is only slightly wider than the diaphysis. The medial articular surface is rounded and the lateral one is sub-quadrate. Both articular surfaces are shallow and wide, surrounded by a welldefined rim, which is better visible in cranial aspect. The lateral tuberosity is strong. The radial tuberosity is thin and laterally extended. In SIT 319, a small part of the ulna can be observed caudally. The attachment of the ulna on the caudal side of the caput is well marked. In SIT 937, the distal part of the radius is preserved. The surface of articulation with the carpal bones is partly eroded, but most of the other characters of the trochlea are present. The groove for the extensor carpi radialis and the common extensor tendon is wide and shallow, limited by two blunt crests, which run parallel to each other and to the long axis of the radius. The processus styloideus medialis is thin and extended distally. The medial protuberance of the trochlea is well-developed. The crests of the lunar facet are not parallel, with the medial rim forming a straight crest, which runs from the cranial to the caudal side, and the lateral rim being short and concave.

Carpus. The magnum-capitatum (SIT 542; Figure 4.4) has a rectangular shape in cranial aspect. The medial groove is relatively deep, limited by two sharp crests, which are unequally developed in posterolateral view. The articular surface for the scaphoid is deep and slightly elongated, running perpendicularly to the axis of the articular surface of the lunatum. The articulation surface for the hamatum is narrow, but relatively high.

Metacarpus. Specimens SIT 920 (Figure 4.11) and SIT 1235 (Figure 4.10) are almost completely unmodified, revealing all the typical characters of Helladotherium, whereas SIT 300 is poorly preserved (Figure 4.9). On the proximal articulation, the facet for the magnum-capitatum is sub-quadrate, and the facet for the hamatum is sub-triangular. Both are shallow with the latter being slightly more concave. The crest between the two facets is thin but well-defined, running through the whole articular surface, from dorsal to palmar side. The sinovial grove is open in palmar aspect. The medial and lateral protuberances are well developed. The sulcus longitudinalis palmaris is relatively shallow. Distally and in dorsal aspect, the keels of both lateral and medial trochleae are blunt and rather narrow, becoming gradually sharper in palmar view. The keels extend on the level of the suture between the caput and the diaphysis.
Tibia. The tibia (SIT 317, SIT 1255; Figure 4.7-8) is robust with a very robust cranial border. On the proximal articular surface, the medial condyle is large and sub-rounded. The lateral condyle is strongly convex, leading to a strong lateral tubercle of the tuberculum intercondylare laterale. The medial intercondylar tubercle is also very well developed and longer than the lateral tubercle. The popliteal notch is very robust, creating a large and blunt protuberance on caudal aspect. The tibial tuberosity is high and slightly curved laterally. On the distal articular surface, the malleolus medialis is not strongly developed. The groove for the tendon of $\mathrm{m}$. flexor digitorum medialis is well-pronounced. In caudal view, the same groove runs up the shaft, further than the level of the suture of the distal epiphysis with the diaphysis. The facets for the astragalus are parallel, with the lateral one being slightly larger.

Malleolus. The lateral malleolus (SIT 1002; Figure 4.17 ) is very long and robust. In lateral aspect, the malleolar groove is very weak. The fibular furrow is sub-triangular and long. The cranial edge is blunt and smooth, almost semi-circular in lateral view

Astragalus. The astragalus (SIT 1005; Figure 4.14) is robust with the lateral and medial proximal trochleae running parallel to each other. The proximal intertrochlear groove is wide and shallow. The lateral trochlea extends higher than the medial one. The same can be observed distally, where the lateral distal trochlea extends lower than the medial one. The distal part is generally more developed than the proximal part. Right below the intertrochlear groove there is a shallow canal that interrupts the development of the articular ridges distally. On the medial aspect, the medial trochlear groove extends more distally than the level of this canal.

Calcaneum. On the calcaneum (SIT 315, SIT 1004, SIT 922; Figures 4.13, 4.14, 4.16), the sustentaculum tali is strong and medially projected, creating a right angle with the long axis of the bone. The groove for the tendon of $\mathrm{m}$. flexor digitorum lateralis is smooth and convex, extending cranially. In lateral aspect, the articular surface for the cubonavicular is concave and the articular surface for the lateral malleolus is semicircular and smooth. Right above the cubonavicular articular surface, there is a wide canal, parallel to the axis of the sustentaculum tali that runs until the articular surface of the astragalus.

Tarsus. On the cubonavicular (SIT 1059; Figure 4.15), the medial astragalar facet is long and wide. The lateral one is as wide as the medial but notably 
shorter. The calcaneal facet is elongated and sub rectangular. In cranial aspect, the medial crista is strong and extended cranially. The articular surface for the cuneiform is sub-rounded and elongated. The facet for the metatarsal bone is sub-triangular.

The only cuneiform recorded from the SIT collection is part of the block SIT 992 (Figure 4.16). Due to the fragility of the specimen, the detachment of the cuneiform is impossible without destroying the rest of the elements. For that reason, no measurements were taken, and no detailed description was possible.

Metatarsus. The metatarsal (Figure 4.12) is robust, with the proximal epiphysis (basis) extending mediolaterally. The robusticity index cannot be calculated since both metatarsal specimens (SIT 301 and SIT 938) are not complete and maintain only the basis of the bone. The proximal metatarsal canal is thin and elongated in proximal aspect. The medial and lateral tubercles on the plantar aspect are very well developed leading to the plantar crests, which are blunt and strong. These crests limit the plantar longitudinal groove, which is very shallow. The dorsal longitudinal groove is also shallow, but as it runs distally it gets thinner and slightly deeper.

The proximal phalanges (SIT 1250, SIT 310, SIT 311; Figure 4.18) are robust, with the base and the head extending only slightly mediolaterally. On the fovea articularis the medial articular facet is almost half the size of the lateral one. The latter is strongly elevated in comparison with the medial facet. The groove in-between the facets is relatively shallow and long, cutting through the palmar rim. The plantar tubercles are robust and long, reaching until almost half of the body. The caput is asymmetrical, with the medial trochlea being moderately longer than the lateral one.

The articular surface of the distal phalanx (SIT 541; Figure 4.19) is long and wide. The articular surfaces for the lateral and medial trochleae of the second phalanx are almost equally developed, with a weak crest dividing them. The margo dorsalis is convex and smooth until the extensor process. The tuberculum flexorium is elongated and rough.

\section{Comparisons}

Large-sized Mediterranean late Miocene giraffid forms are usually referred to the genera Helladotherium or Samotherium Forsyth-Major (1888). However, these two taxa belong to two separate subfamilies, Sivatheriinae and Palaeotraginae, respectively (Bohlin, 1926; Hamilton, 1978; Geraads, 1986). Latest phylogenetic analysis groups them together in a larger Samotherium-Sivatherium clade (Ríos et al., 2017). Gaudry (1861), erected Helladotherium on a collection of fossil specimens from Pikermi, of unknown stratigraphic origin and with no designated holotype. H. duvernoyi first appeared at the end of Vallesian-beginning of Turolian and during the MN12 it became more abundant (Kostopoulos and Saraç, 2005). There is only one species assigned to the genus, which appears in several localities of Greece, spanning from MN9 to MN13 (Marinos and Symeonidis, 1974; Solounias, 1981a; Solounias, 1981b; Bonis et al., 1992; Kostopoulos et al., 1996; Athanassiou, 2002; lliopoulos, 2003; Kostopoulos et al., 2003; Kostopoulos and Koufos, 2006; Koufos, 2006; Kostopoulos, 2009). The taxon has also been reported from the late Miocene of France Bulgaria, Former Yugoslav Republic of Macedonia (F.Y.R.M.), Georgia, Hungary, Iran, Turkey, Ukraine, Algeria and Tunisia (Gaudry, 1873; Bakalov et al., 1962; Churcher, 1978; Geraads and Güleç, 1999; Gentry, 2003; Geraads et al., 2005; Karadenizli et al., 2005; Kostopoulos and Saraç, 2005; Vangengeim and Tesakov, 2008; Vekua and Lordkipanidze, 2008; Geraads, 2009; Yilmaz, 2011; Kostopoulos and Sen, 2016; Solounias and Danowitz, 2016a).

The metrical and morphological characters of the above-described large-sized giraffid from Thermopigi fall within the range of Helladotherium (Bohlin, 1926; Geraads, 1986; Geraads et al., 2005; Kostopoulos and Koufos, 2006; Geraads, et al. 2007; Kostopoulos, 2009; Kostopoulos, 2016) and are clearly distinct from other large-sized late Miocene giraffids, such as Samotherium. The deciduous premolars found at SIT are of similar size as those of Helladotherium duvernoyi and are always larger than the ones of Samotherium major and Alcicephalus neumayri Rodler and Weithoffer (1890) (Figure 5). The D2 (SIT 1425) is larger than most of the Helladotherium specimens from Samos and Perivolaki. More specifically SMF24431, which is the largest deciduous dentition from Samos (Kostopoulos, 2009), is wider but shorter than SIT 1425. A similar pattern can be observed with the D3 and D4 (SIT 1260 and SIT 671, respectively), which, similarly to SIT 1425, appear slightly larger than the Helladotherium specimens from Perivolaki. Morphologically, SIT 1425 shows many similarities to the Helladotherium specimen from Perivolaki (PER 264) with the only difference being the slightly longer and slenderer anterior cone. In comparison to other taxa, the milk dentition of Samotherium is shorter and narrower, especially 

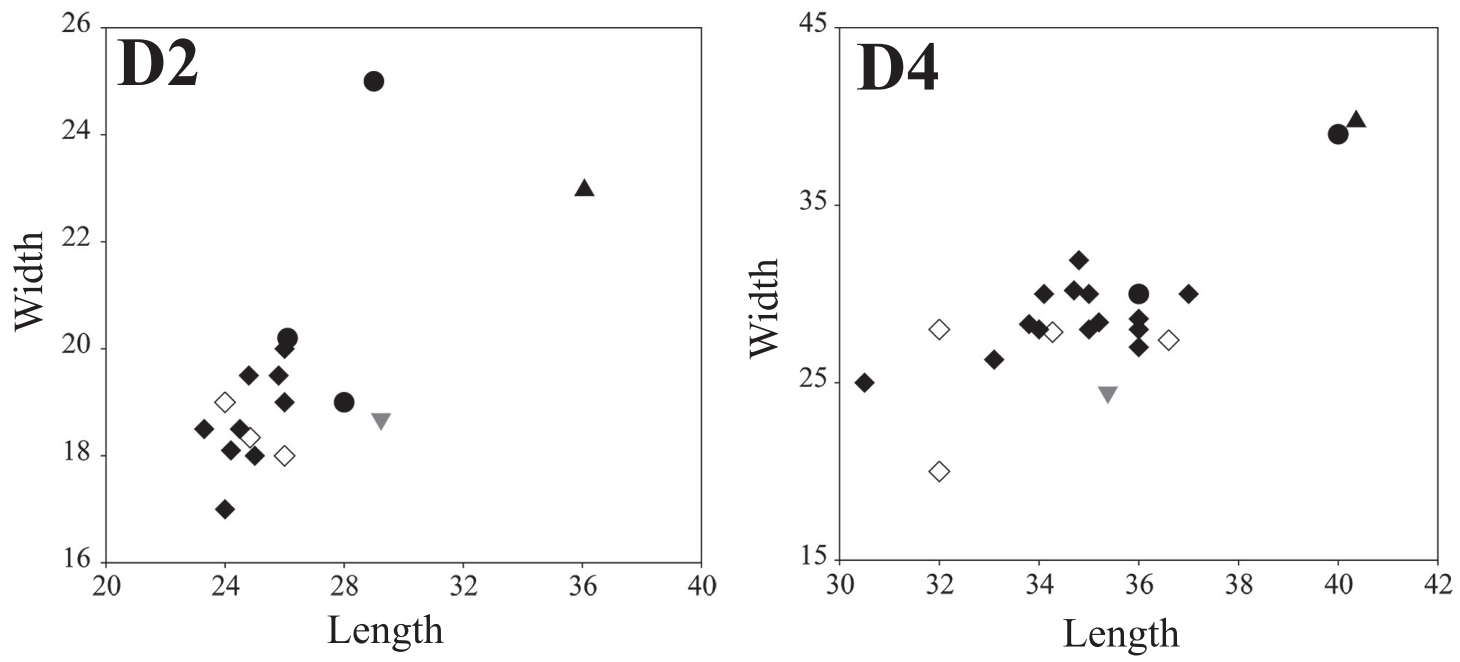

SYMBOL LEGEND

Helladotherium duvernoyi

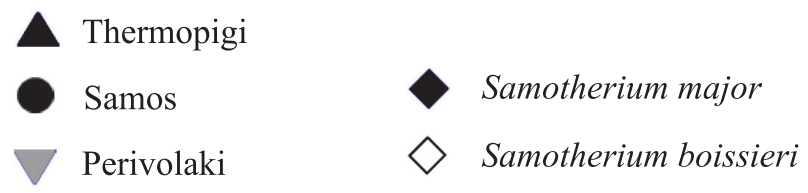

FIGURE 5. Dispersion plots showing length versus width of the second (up) and fourth (down) deciduous premolars of Helladotherium duvernoyi, compared with findings from other Greek localities. All measurements given in $\mathrm{mm}$ (data from Kostopoulos and Koufos, 2006; Kostopoulos, 2009; this study).

regarding D2 and D3 (Kostopoulos, 2009). The same pattern can be observed in $A$. neumayri from Maragheh (A4558; plate IV, figure 1 in Rodler and Weithofer, 1890) where the two first deciduous premolars are also narrower and shorter. SIT 1260 has a long anterior cone, and it is also very similar to PER 264. The D3s of A4558 and PIM299 (Kostopoulos, 2009), from Maragheh and Samos, respectively, are shorter with the anterior lobe being almost as large as the metacone. The D4 looks similar in all specimens except that the labial styles are much stronger and robust in SIT 671 and PER 264 than in A. neumayri from Maragheh and $S$. major from Samos. The sharp and strong entostyle in SIT 671 is absent from the specimen of Perivolaki. Metrically, SIT 671 is larger than other D4s from Perivolaki and Samos (Figure 5).

SIT 1254 represents an almost complete upper toothrow. The premolar length is large, and it appears to be larger than all the studied Helladotherium specimens from Greece and Bulgaria (Figure 6). All the premolars from Thermopigi (SIT 1254, SIT 1001, SIT 1251, SIT 651) are very large, plotting close to the largest Helladotherium speci- mens from Pikermi, Samos, Kerasia and Maragheh (Figure 7). The length of the premolars gradually declines distally. P2 and P3 are consistently long but not wider than the Helladotherium specimens from Kalimantsi and Pikermi (Figure 7). The P4 is still plotting among the largest Helladotherium specimens but it is slightly smaller than some from Pikermi and Samos (Figure 7). The M1 and M2 from Thermopigi (SIT 1254) are not significantly larger than specimens from other localities. More specifically, both molars seem to plot right between the morphospaces of $H$. duvernoyi from Pikermi and S. major and Alcicephalus neumayri from Samos and Maragheh, respectively. Even though the premolars of the holotype of $H$. duvernoyi, illustrated by Gaudry (1862-1867), show that the occlusal surfaces of the premolars are almost completely unworn, the general morphology agrees with SIT 1254. Additionally, the P2 and P4 do not show significant differences compared to the Bulgarian Helladotherium specimen (K-5156; plate I, figure 1 in Geraads et al., 2005) but in the latter, the P3 is much less triangular with less developed labial styles. The M1 is very worn in 


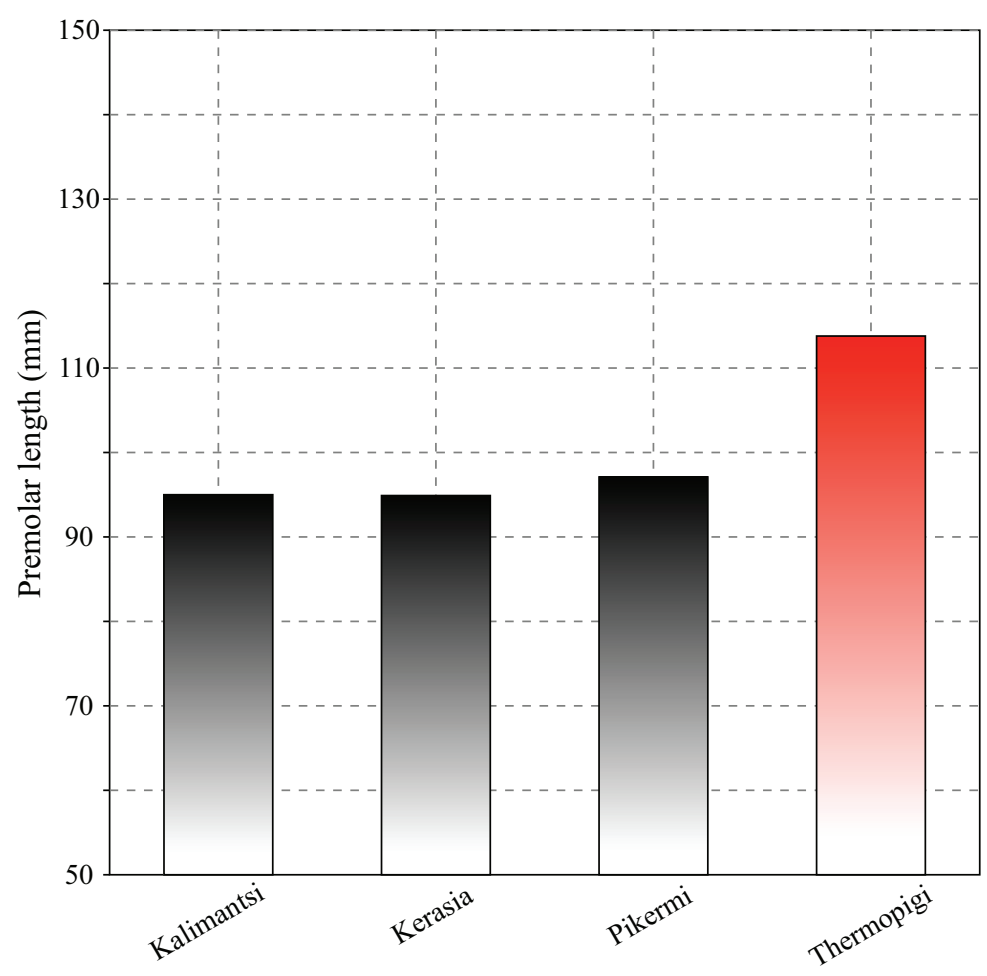

FIGURE 6. Barchart showing the range of upper premolar length in Helladotherium duvernoyi from Thermopigi, compared with other localities (data from Bohlin, 1926; Iliopoulos, 2003; Geraads et al., 2005; this study).

both specimens, while the fosseta, as well as the lingual cingulum of the $M 2$ are characters that are missing from the Bulgarian specimen.

Scapulae of fossil giraffids are scarce. Nevertheless, the available fossil record reveals some significant differences on the scapulae of Sivatheriinae and Palaeotraginae. The scapula of Helladotherium possesses a pentagonal-shaped glenoid cavity with a moderately developed supraglenoid tuber. In Samotherium, as well as other palaeotragine taxa, the glenoid cavity is oval shaped and the supraglenoid tuber is positioned at a higher level (plate III, figure 1a-c in Borissiak 1914; plate VIII, figure 7 in Bohlin 1926; figure 4a in Godina, 1979; Kostopoulos, 2009; Kostopoulos, 2016).

The limb bones of Helladotherium duvernoyi and Samotherium major show a very apparent metrical overlapping. Nevertheless, there are distinct morphological differences on the limb bones of both taxa. Detailed descriptions of characters of post-cranial elements of both $H$. duvernoyi and $S$. major, were given by Kostopoulos (2009), Ríos et al. (2016), and Solounias and Danowitz (2016b).

Helladotherium duvernoyi exhibits a very high size variability (Roussiakis and Iliopoulos, 2004;
Kostopoulos, 2009). Following the suggestion that size variation is more prominent in the transverse and anteroposterior diameters of the proximal and distal epiphysis (Roussiakis and lliopoulos, 2004) the proximal transverse diameter/proximal anteroposterior diameter ratio of metacarpals and metatarsals was calculated (see Appendices 2 and 3). These ratios were compared with measurements of respective post cranial elements from other localities (Figure 8). Metacarpals and metatarsals exhibit a particularly prominent range, which may indicate a relatively high sexual dimorphism (Roussiakis and Iliopoulos, 2004). Thus, indicating the presence of two different size groups of Helladotherium at Thermopigi, a very large group of male individuals, which is represented by dental and postcranial elements and a smaller group of female or younger individuals which are represented by a few limb bones.

Subfamily PALAEOTRAGINAE Pilgrim, 1911

Genus SAMOTHERIUM Forsyth-Major, 1888

Type species. Samotherium boissieri ForsythMajor, 1888

Samotherium major (Bohlin, 1926) Figure 9 

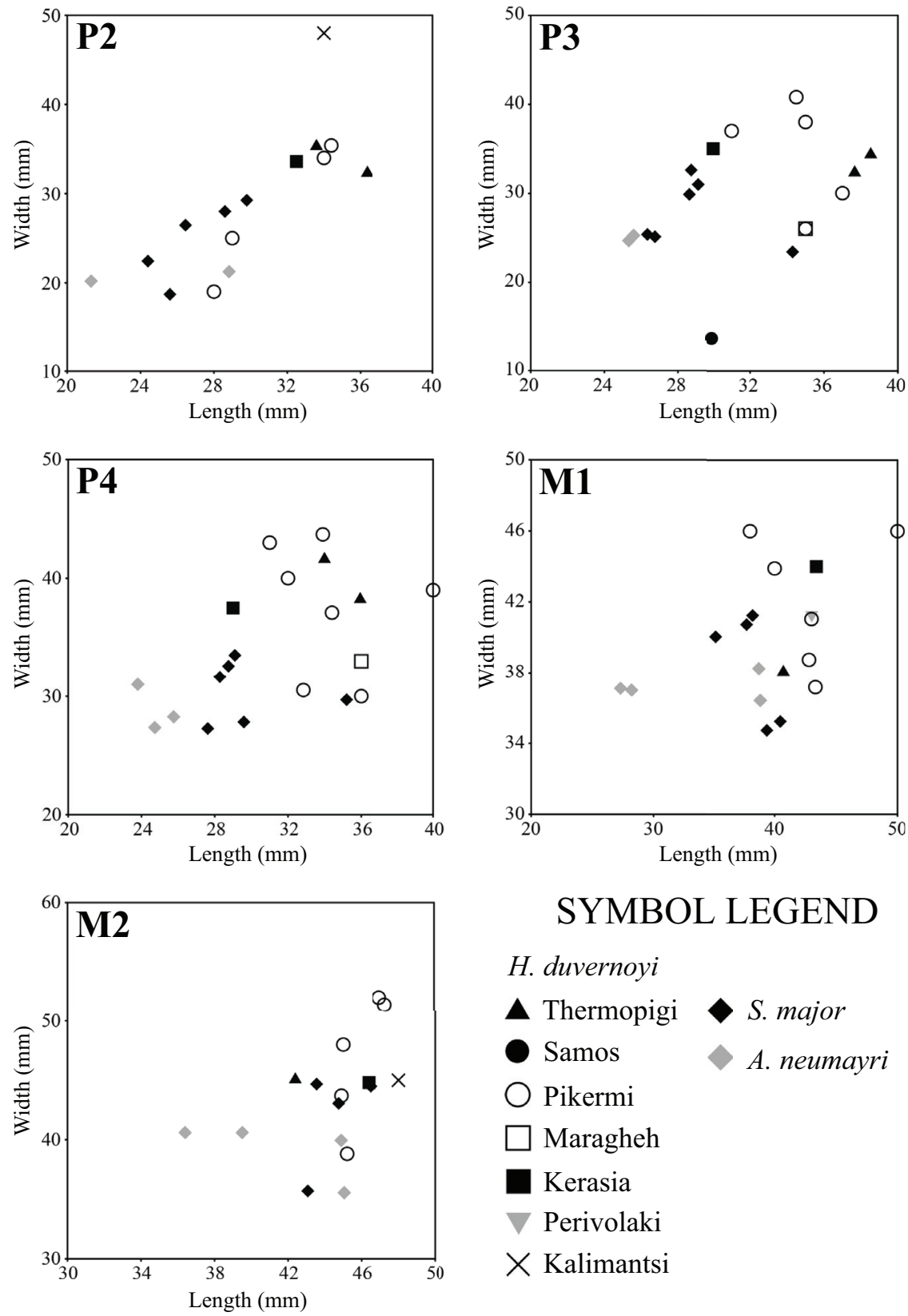

\section{SYMBOL LEGEND}

H. duvernoyi

$\Delta$ Thermopigi $>$ S. major

Samos

$\bigcirc$ Pikermi

A. neumayri

$\square$ Maragheh

Kerasia

Perivolaki

$\times$ Kalimantsi

FIGURE 7. Scatter plots comparing dental measurements in Helladotherium duvernoyi from various localities. All measurements given in mm (data from Bohlin, 1926; Bakalov et al., 1962; lliopoulos, 2003; Geraads et al., 2005; Kostopoulos and Koufos, 2006; this study).

\section{Material}

Left scapula (SIT 922), distal part of left humerus (SIT 313), complete left radius-ulna (SIT 312), complete left radius-ulna (SIT 1020), proximal part of radius (SIT 1352), complete right metacarpal (SIT 314), distal part of right metatarsal (SIT 859).

\section{Descriptions}

Samotherium major is the least abundant giraffid at SIT. No dental material was found. Nevertheless, a small collection of forelimb elements reveals all the diagnostic characters of the species. Scapula. The scapula (SIT 922; Figure 9.1) is fragmented dorsally and the dorsal margin is not preserved. In cranioventral aspect, the glenoid cavity 

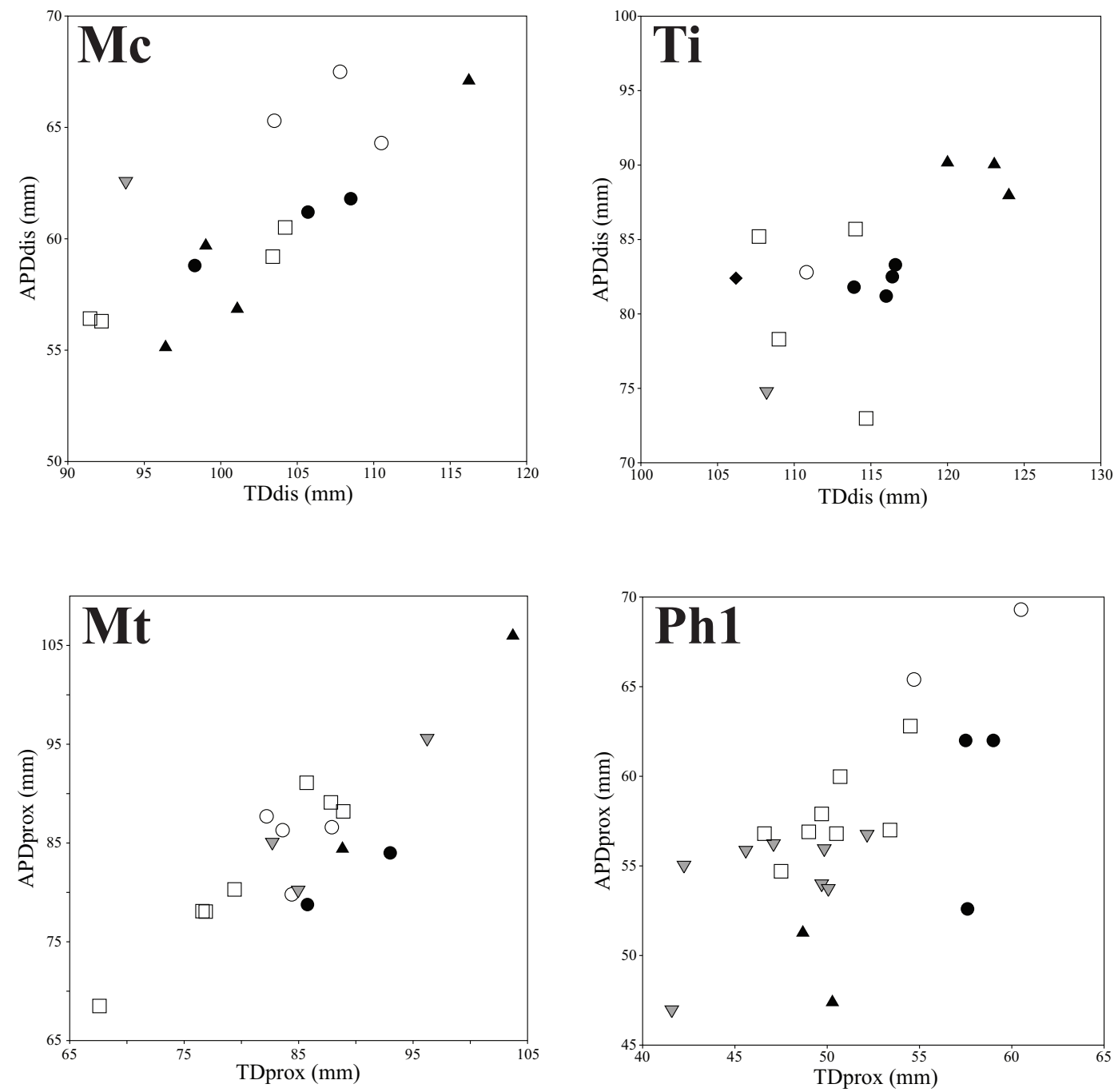

SyMBOL LEGEND
A Thermopigi
Pikermi
$\nabla$ Perivolaki
O Kerasia
- Samos
Akkaşdağ 1

FIGURE 8. Scatter diagrams comparing limb proportions of Helladotherium duvernoyi from different Greek localities. TD: transverse diameter; APD: antero-posterior diameter; prox: proximal; dis: distal. All measurements given in mm (data from Iliopoulos, 2003; Kostopoulos and Saraç, 2005; Kostopoulos, 2009; this study).

shows an egg-shaped outline. The lip of the glenoid cavity is preserved cranially and only partly, and it is sharp and well developed. In lateral aspect, the supraglenoid tuber is well developed, forming an approximately $65^{\circ}$ angle with the scapular notch. The neck of the scapula is short, making the distance between the lip of the glenoid cavity and the spine very short. The spine is strong and extended cranially, forming a $27^{\circ}$ angle with the axis of the scapula, covering the fossa supraspinata completely. In cranioventral aspect, the spine is curved forming a reverse $\mathrm{C}$ with the tuberculum supraglenoidale. The morphology of the fossa infraspinata is similar to $H$. duvernoyi, but in the latter all the characters are notably more robust. Caudally, in the area of the attachment of the teres major and teres minor muscles, the surface of the fossa gets gradually thicker possibly 

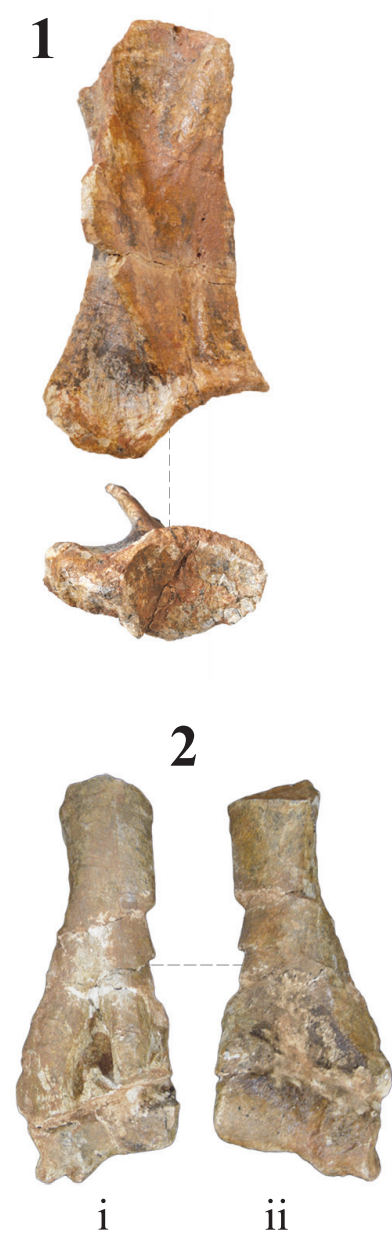

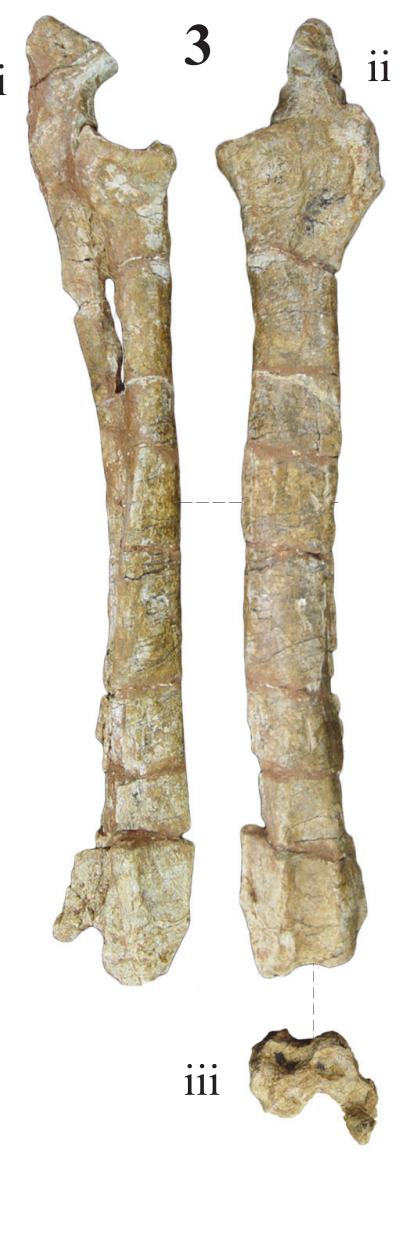

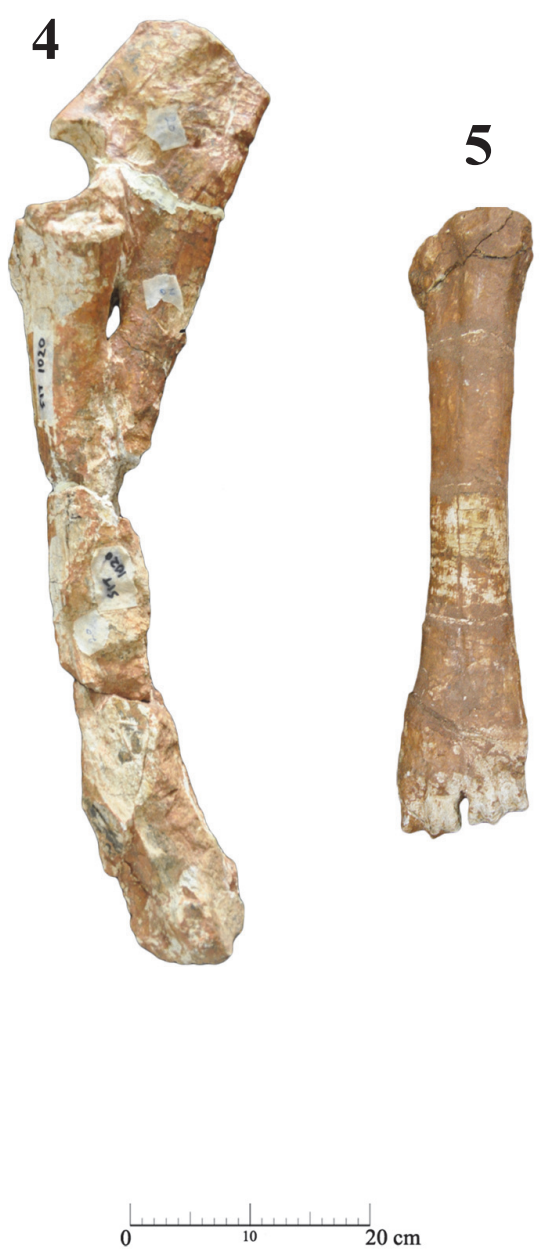

FIGURE 9. Post-cranial fossil material of Samotherium major from Thermopigi: 1, SIT 922, left scapula, (i) lateral view and (ii) cranioventral view; 2, SIT 313, distal part of left humerus, (i) caudal view and (ii) cranial view; 3, SIT 312, complete left radius-ulna, (i) lateral view, (ii) cranial view and (iii) medial view; 4, SIT 1020, complete left radius-ulna; 5, SIT 314 , right metacarpal (Mc III+IV). Scale equals $20 \mathrm{~cm}$.

leading to a strong angulus caudalis. Medially, the subscapular fossa is very shallow.

Humerus. SIT 313 (Figure 9.2) maintains only the distal part of a humerus as well as a part of the diaphysis. The crest of the humerus is almost flat, revealing a weak torsion of the bone. In cranial aspect, the radial fossa is not visible due to deformation. The trochlea is symmetrical, with the medial and lateral condyles being equally developed. The lateral surface of the medial condyle is flat, running parallel to the long axis of the bone. Caudally, the crista supracondylaris lateralis is not as strong. Lateral and medial epicondyles are equally developed. The olecranon fossa is narrow and deep, creating a valley, which extends almost until the root of the crista supracondylaris lateralis.
The keel of the lateral condyle is blunt and wide and the groove between the two condyles forms a very open angle caudally, which closes and deepens, as it runs cranially.

Radius-UIna. The radius (SIT 312, SIT 1020; Figure 9.3-4) is relatively slender, with the head and the trochlea extending mediolaterally. The lateral and medial articular surfaces are sub quadrate in proximal view, with the latter being relatively deep. In cranial aspect, the radial tuberosity extends anterolaterally, and the lateral protuberance is fairly developed. The medial keel of the lateral surface, as well as the keel that separates the medial from the lateral articular surfaces, are well defined and blunt in proximal view, but they create two strong and evenly elevated rims in cranial aspect. In the 
same perspective, the medial articular surface is oblique, creating an approximately $65^{\circ}$ angle with the long axis of the radius. The groove for the extensor carpi radialis and the common extensor tendon is relatively deep, with the lateral and medial rims being strong and slightly tilted towards the long axis of the bone. Both lateral and medial styloid processes are equally developed, reaching the same level distally. The crests of the lunar facet are parallel.

SIT 1020 reveals a very long and robust ulna. The olecranon is high and wide in lateral aspect, but the tuber olecrani is missing. The incisura trochlearis is triangular, pointy and slightly curved towards the fovea capitis radii. The lateral coronoid process is weak and blunt in contrast with the medial coronoid process, which is more developed and sharper. The proximal interosseous space between radius and ulna is narrow and long.

Metacarpus. SIT 314 (Figure 9.5) is slightly modified but it still maintains the distinct Samotherium characters. On the base, the articular facet for the magnum is sub-rounded, and the facet for the hamatum is triangular. The crest that separates the two facets is well defined but not as much toward the palmar side. The sinovial fossa is closed. The sulcus longitudinalis palmaris is deep. The medial and lateral rims are strong and blunt from the canalis metacarpi proximalis, until the level above the suture of the distal articulation with the diaphysis.

\section{Comparisons}

Forsyth-Major (1888) erected Samotherium based on large ruminant remains found at Samos. What at first appeared to be remains of Helladotherium, later gave birth to Samotherium boissieri (Forsyth-Major, 1891), but no holotype was designated. Bohlin (1926) described S. major as a variety of S. boissieri and later, Geraads (1994) defined a female skull from Samos, stored in the Natural History Museum of Basel (NHB no Sa. 29) as a lectotype of S. major.

Samotherium major has been reported from the Turolian (MN 12-13) of Samos, Vathylakkos and Kerasia (Solounias, 1981a; Solounias, 1981b; Iliopoulos, 2003; Kostopoulos et al., 2003; Koufos, 2006; Kostopoulos, 2009 and literature within). The species has also been found in Kemiklitepe A/B, Akkaşdağı and Taşkinpaşa (Şenyürek, 1954; Geraads, 1994; Saraç, 2003; Karadenizli et al., 2005; Kostopoulos and Saraç, 2005; Kostopoulos, 2009).

The humerus (SIT 313) falls within the metrical variation of the species. The transverse diameter of the distal epiphysis is $124.3 \mathrm{~mm}$, which is slightly smaller than the humeri from Kerasia and Samos (lliopoulos, 2003; Kostopoulos, 2009). The range for the transverse diameter of the distal epiphysis for Samotherium boissieri from Samos is 84.5-106.0 mm (lliopoulos, 2003) and for Samotherium major from Samos and Kemiklitepe is 116.0148.2 mm (Geraads, 1994; Iliopoulos, 2003; Kostopoulos, 2009). The same measurements for $\mathrm{Hel}-$ ladotherium duvernoyi from Pikermi, Samos and Kerasia vary between $127.0-158.5 \mathrm{~mm}$, showing a significant metrical overlapping. That brings SIT 313 closer to $S$. major from Samos, agreeing with the morphological data. Even though only the distal part of the humerus is maintained, as well as a small part of the diaphysis, it is notable that the torsion of the humeral body is weak. Additionally, the asymmetrical distal trochleae as well as the narrow and deep olecranon fossa, are considered as diagnostic characters of S. major (Kostopoulos, 2009).

The radii from Thermopigi (SIT 312 and SIT 1020) are very long and slender. Both specimens are longer than the radii from Kerasia and Samos (Figure 10). The variation in size of the transverse diameter of the proximal epiphysis of Samotherium major is 124-152 mm (lliopoulos, 2003; Kostopoulos, 2009; and pers. data AX) and both specimens from Thermopigi fall within this variation. Despite the length of SIT 312 and SIT 1020, morphological characters support their inclusion within $S$. major. The proximal articular facets are deep with the medial one being oblique in relation to the long axis of the bone. These characters, in combination with the strong and well-defined grooves for the extensor carpi radialis and the common extensor tendon are enough to attribute these slender and long radii to S. major (Kostopoulos, 2009).

The basis of the metacarpal (SIT 314) presents a closed sinovial fossa and well-developed palmar tubercles. Metrically, SIT 314 is longer and with a stronger diaphysis than observed in the specimens from Samos and Kerasia (Figure 10).

Though the above-described characters are undoubtedly disclosing the presence of Samotherium major in Thermopigi, the measurements reveal a general size increase of the taxon. In fact, this size upsurge is rather common for most giraffid taxa of Thermopigi (Helladotherium duvernoyi and Palaeotragus sp.). The radius and the metacarpal show a significantly increased length. However, the transverse diameters of the proximal epiphysis and the diaphysis reveal rather usual values (Figure 11). Thus, the available material of $S$. major is typified by a general elongation of the limb bones, without significant metrical changes in the diame- 

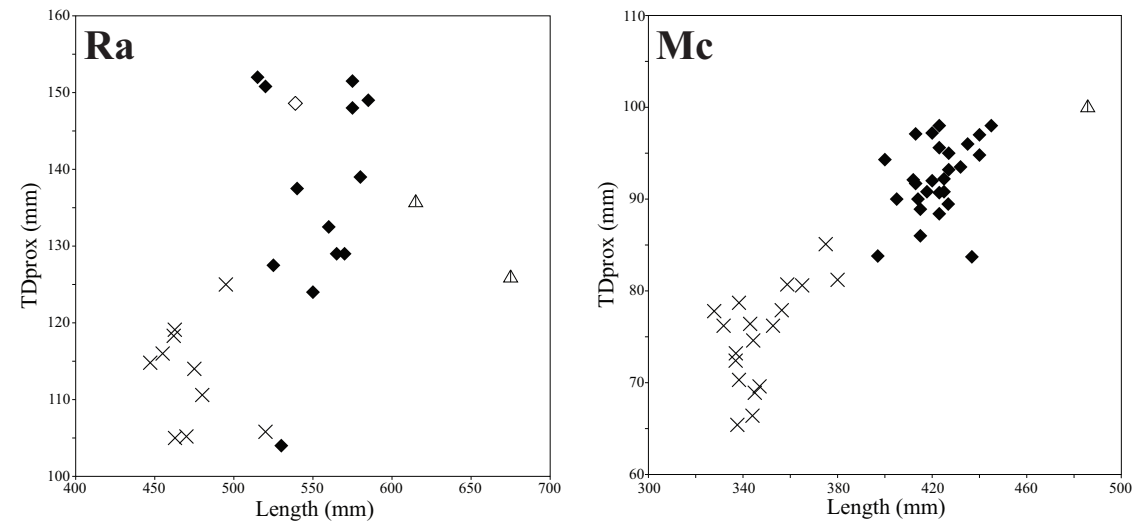

SYMBOL LEGEND

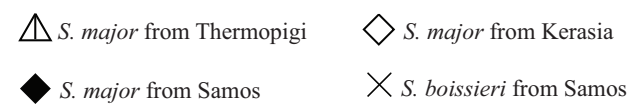

FIGURE 10. Bivariate plots for radii (Ra) and metacarpals (Mc) of Samotherium major from Thermopigi compared to Samotherium findings from Samos and Kerasia. All measurements given in mm (data from Iliopoulos, 2003; Kostopoulos, 2009; this study).

ters of the basis and the shaft. In addition, the large size of $H$. duvernoyi unveils a size increase in both large giraffids of Thermopigi possibly due to internal ecological competitions.

Samotherium constitutes an important late Miocene samotheriine. Besides the Greek forms, S. boissieri and S. major, the late Miocene fossil record includes Alcicephalus neumayri from Maragheh, S. sinense Bohlin (1926) from China, S. eminens Alexeiev (1916) and $S$. maeoticum Korotkevich (1978) from Ukraine, as well as $S$. borissiaki Godina (2002) and S. korotkevichae Godina (2002) from Moldova, which are poorly described (Kostopoulos, 2009; Hou et al., 2014). The presence of Samotherium at Thermopigi, constitutes the third documented record of the taxon in Greece, and the northernmost occurrence of $S$. major.

Subfamily PALAEOTRAGINAE Pilgrim, 1911 Genus PALAEOTRAGUS Gaudry, 1861

Type species. Palaeotragus rouenii Gaudry, 1861

Palaeotragus rouenii (Gaudry, 1861) Figure 12

\section{Material}

Part of left maxilla with P2-M2 (SIT 1253), part of left maxilla with M3 (SIT 1153), left humerus (SIT 939), right radius (SIT 1256), left metacarpal (SIT 302), right metacarpal (SIT 303), left metatarsal (SIT 307), right metatarsal (SIT 970).

\section{Descriptions}

The cranial material of Palaeotragus rouenii from Thermopigi is limited to two maxillary fragments. Lower teeth and mandible fragments are absent. However, there is a wider variety of postcranial elements. The front limb is represented by a humerus, a radius and two metacarpal bones. The hind limb is represented by two metatarsal bones.

Dentition. Specimens SIT 1253 (Figure 12.1) and SIT 1153 (Figure 12.2) comprise a complete left maxilla. SIT 1253 lacks the M3 but based on the measurements of SIT 1153 the estimated length of the toothrow is $123 \mathrm{~mm}$. The premolar length is $49.34 \mathrm{~mm}$. The P2 is smaller than the other two premolars, and it is relatively rounded, in occlusal aspect. The lingual cone is well-developed, and there is no cingulum. The anterior and posterior styles are labially projected. The anterolabial cone is robust, creating a labial sharp style, which is tilted anteriorly. The fossa is wide.

The P3 is oval-shaped in occlusal view. The posterolingual cone is more developed than the anterolingual cone, leading to the elliptical shape of the tooth. The central fold is elongated, pointing towards the posterolabial crista. The fossa is wide and interrupted by a smaller fold on the level between the anterolabial and anterolingual crista.

The P4 is similar to the P3, but more rectangular in occlusal aspect. The anterolingual and posterolingual cones are strong and equally pro- 

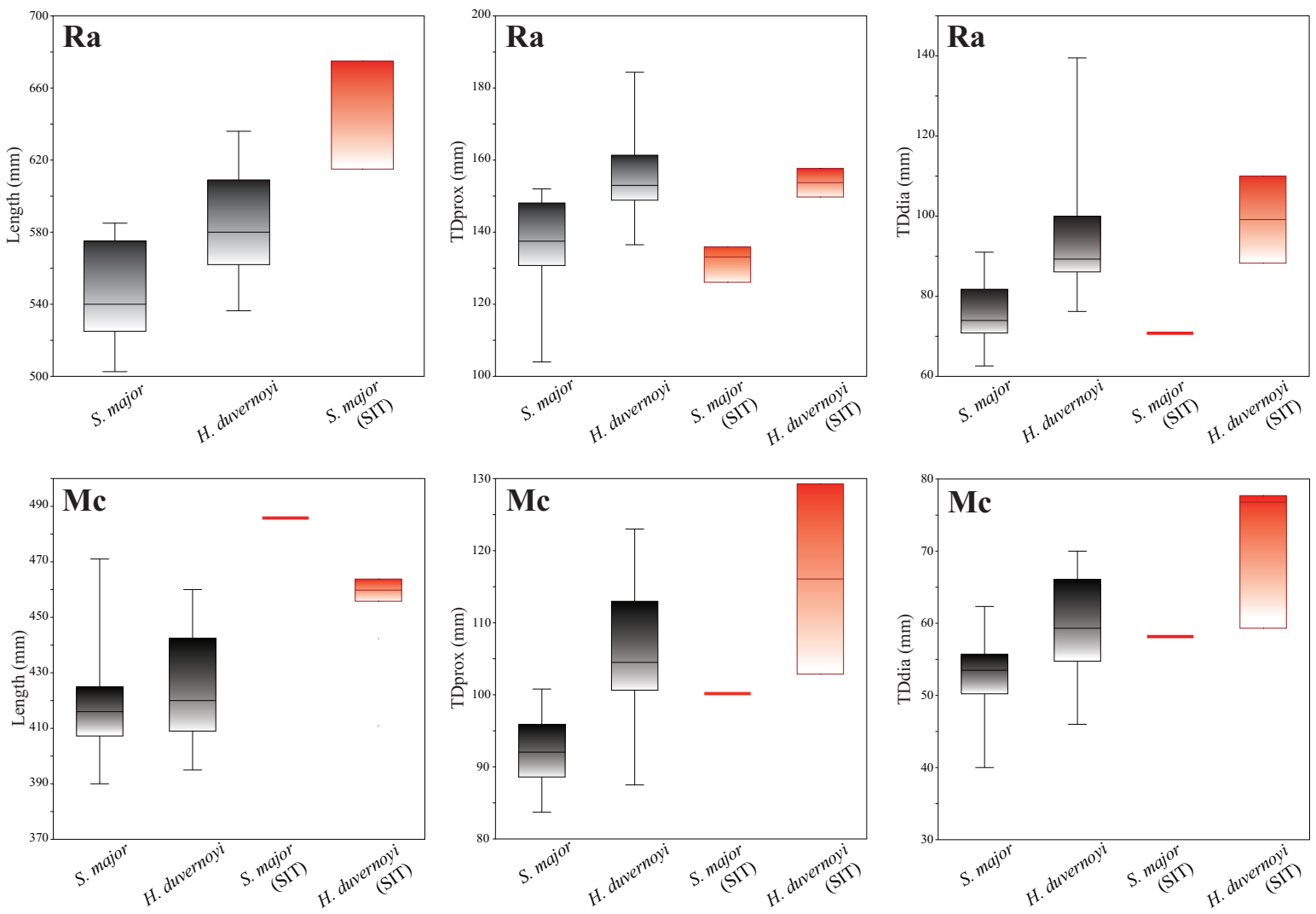

FIGURE 11. Boxplots of ranges or different measurements of radii (Ra) and metacarpals (Mc) of Samotherium major and Helladotherium duvernoyi from Thermopigi (SIT) in comparison with respective measurements from other various localities. Each box represents $50 \%$ of the range of each measurement. The top and the bottom bars represent the overall range of the length. The vertical line in the center of each box represents the median of the sample. TD: transverse diameter; prox: proximal; dia: diaphysis. All measurements are given in mm (data from Iliopoulos, 2003; Kostopoulos, 2009; Ríos et al., 2016; this study).

nounced, creating a continuous basal protuberance, which give the tooth its rectangle shape. The labial styles are parallel to each other, and the anterolabial cone is blunt and well pronounced. The central fold is bifurcated creating a Y-shaped structure on the posterolingual crista.

The protocone of the M1 is very well developed with a weak cingulum towards the external postprotocrista. The preprotocrista is smooth and runs in a straight line towards the parastyle. The latter is strong and rounded. The preparacrista is thin, and the paracone is strong with a well-pronounced labially pillar. The postparacrista becomes thinner towards the mesostyle, which is broken. The metacone is thin, without any labial pillars. The external postmetaconule crista shows a small Ushaped structure on the enamel ridge, and the metaconule is strong at the base of the crown, almost creating a style.
The M2 is slightly larger than the M1. The mesostyle is well-developed and projecting labially. There is a very weak, rounded protocone fold projecting towards the fossa. The apex of postprotocrista is bifurcated. At the base of the metaconule, on the level of the external premetaconule crista, a small and pointy style can be observed. The same style is more pronounced on the M3 (SIT 1153). Mesostyle and metastyle are robust and rounded. The labial pillar of the paracone is stronger than on the other two molars.

Humerus. Specimen SIT 939 (Figure 12.3) consists of an almost complete humerus, with the proximal articulation surface being absent. Proximally, the tuberositas teres minor is well developed. The line of origin of caput laterale $\mathrm{m}$. tricipitis brachii is weak but well-defined, running through the shaft, until the upper $40 \%$ of the diaphysis. On the distal condyle, the fossa olecrani is deep and elongated, while the radial fossa is long and shal- 

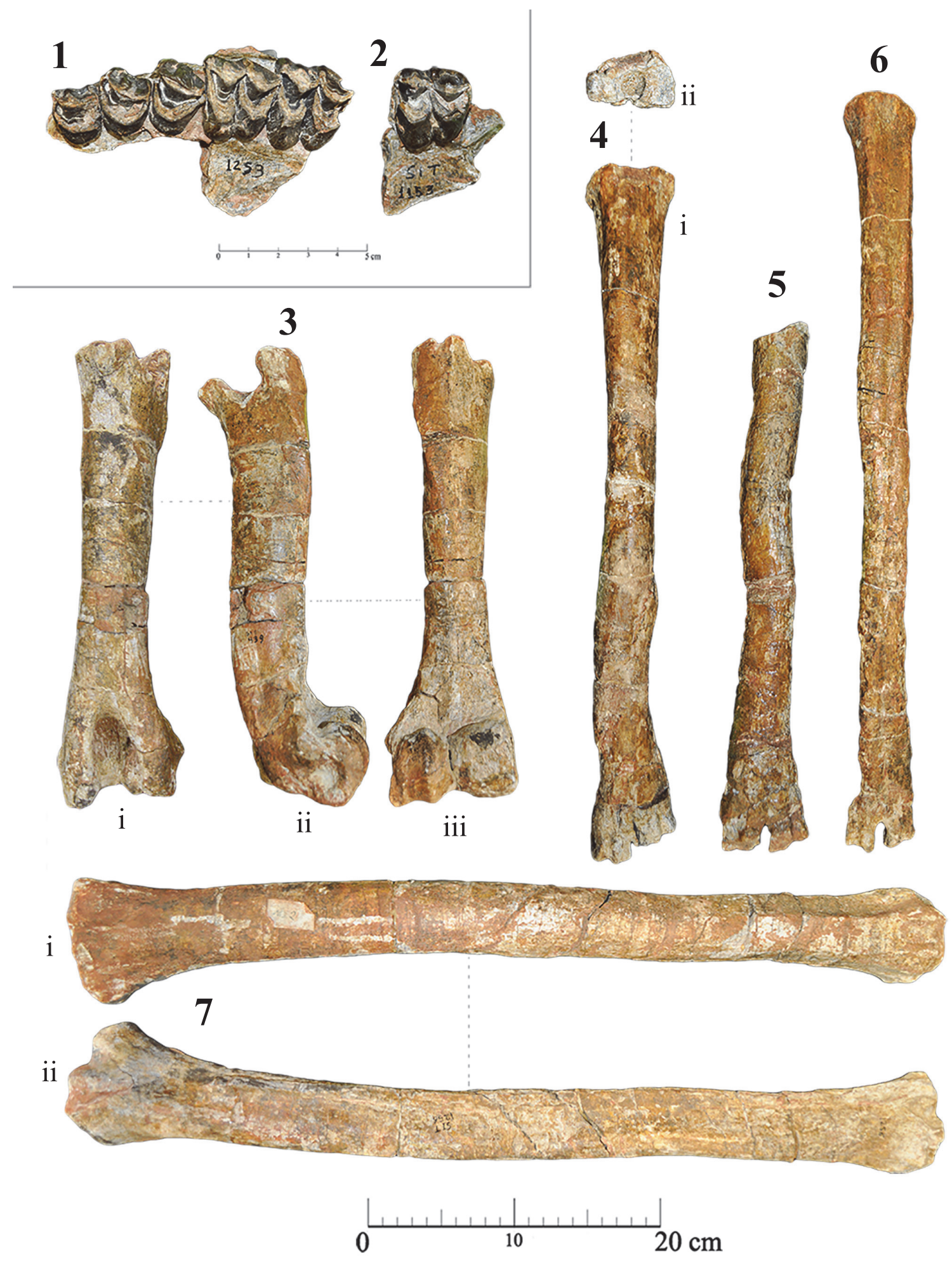

FIGURE 12. Dental and post-cranial fossil material of Palaeotragus rouenii from Thermopigi: 1, SIT 1253, part of left maxilla with P2-M2; 2, SIT 1153, part of left maxilla with M3; 3, SIT 939, left humerus, (i) caudal view, (ii) lateral view and (iii) cranial view; 4, SIT 302, left metacarpal (Mc III+IV), (i) dorsal view and (i) proximal view; 5, SIT 303, distal part and diaphysis of right metacarpal (Mc III+IV); 6, SIT 307, left metatarsal (Mt III+IV); 7, SIT 1256, right radius, (i) cranial view and (ii) caudal view.Scale for dental material equals $5 \mathrm{~cm}$. Scale for post-cranial material equals $20 \mathrm{~cm}$. 
low. The epicondylus medialis is much stronger and more developed than the epicondylus lateralis, which is smooth and almost flat. The distal trochlea is asymmetrical. The medial trochlear keel is wide and blunt, running parallel to the axis of the diaphysis.

Radius. The radius (SIT 1256; Figure 12.7) is complete, with some parts of the ulna still attached. It is slender and long, with the axis being slightly tilted to the left proximally. The head is slightly wider transversely than the distal trochlea. The medial articular surface is much wider and bigger than the lateral one. The radial tuberosity is well-defined, and the lateral tuberosity is thinner, extending laterally. On the distal trochlea, the surface for the extensor carpi radialis tendon is wide and well-pronounced, limited by two lateral blunt crests that run parallel to the axis of the shaft. The surface of the styloid process is broken. The remains of the ulna attached to the radius consist of a small fragment of the processus coronoideus medialis, as well as a part of the lateral surface. The latter starts from the level of the spatium interosseum antebrachii proximale and continues until the apex of the styloid process.

Metacarpus. SIT 302 (Figure 12.4) consists of a complete left metacarpal, with the anterior surface being slightly fragmented and the distal part strongly deformed, whereas SIT 303 preserves the distal part with the diaphysis (Figure 12.5). On the basis, the facet for the magnum is square shaped. The facet for the hamatum is sub-triangular, with the external surface being rounded. The sinovial fossa is large and closed caudally. The dorsal longitudinal groove, as well as the proximal and distal metacarpal canal, are not visible. The carpal tuberosity is fairly developed. The sulcus longitudinalis palmaris is relatively deep with the palmar surfaces being high, forming two parallel blunt crests. The caput is as wide as the base. The keels of the trochleae are blunt dorsally, turning sharper and higher as they run towards the palmar side.

Metatarsus. SIT 307 (Figure 12.6) consists of a complete metatarsal, with both proximal and distal articulation surfaces poorly preserved. Nevertheless, since the diaphysis is fairly preserved, and the maximum length of the bone can be measured, the robusticity index can be calculated (6.13). SIT 970 preserves the largest part of the basis, revealing two well-developed plantar tubercles with the medial one being much stronger than the lateral tubercle.

\section{Comparisons}

The genus Palaeotragus is the best-known fossil giraffe of the late Miocene, and it is highly abundant in the Greco-Iranian province (Gentry and Heinzmann, 1996). However, the phylogenetic relationships of the numerous Palaeotragus species is obscure and questionable. Despite nomenclature issues, the members of the genus Palaeotragus can be separated into two sizegroups (Geraads, 1986; Kostopoulos et al., 1996; lliopoulos, 2003; Kostopoulos and Saraç, 2005; Kostopoulos, 2009). The small-sized group includes taxa such as $P$. rouenii, $P$. microdon Koken (1885) and P. pavlowae Godina (1979), and the large-sized group includes taxa such as $P$. coelophrys and P. quadricornis Bohlin (1926). The small-sized group used to include Palaeotragus primaevus Churcher (1970) from Fort Ternan until the taxon was revised and moved into the genus Giraffokeryx Gray (1821) (Solounias, 2007; Harris et al., 2010). Bohlin (1926) suggested the synonymy of $P$. rouenii and $P$. microdon, but due to the scarcity of material at that time, he kept the species separated. Later, Hamilton (1978), Geraads (1974) and Kostopoulos and Saraç (2005), also suggested that the available material shows significant differences and represents two distinct species. The large-sized group also includes $P$. expectans Borissiak (1914), P. quadricornis, P. borissiaki Alexeiev (1930), $P$. berislavicus Korotkevich (1970), P. asiaticus Godina (1979) and P. hoffstetteri Ozansoy (1965). Geraads (1986) concluded that there were no significant differences among most of these taxa and considered all of them to be synonyms of $P$. coelophrys.

The data presented here show that the smallsized giraffid specimens described above belongs to Palaeotragus rouenii, based on both morphological and size similarities shared with previously studied fossils representing this taxon.

The type specimen of Palaeotragus rouenii (MNHN.F.PIK1670) illustrated by Gaudry (1862-67) (plate XLV, figures 1,2), shows a similar morphology to SIT 1253 and SIT 1153. In the type specimen the degree of wear seems to be lower than that of the specimens from Thermopigi, but nevertheless, the important characters are clearly visible. The P2 and P3 of SIT 1253 exhibit similar morphology to the type specimen, with the lingual cones being slightly more developed and the anterior and posterior styles slightly more projected. The P4 of the same specimen is more triangular in occlusal view than the holotype, which can be due to the wear stage. On the same tooth, the labial 
styles are not as pronounced as on the previous premolars, as also seen in MNHN.F.PIK1670. In the illustration from Gaudry, the posterolingual cingulum of the P4 forms a small style. In SIT 1253, the same cingulum is very well pronounced, which is analogous to the posterolingual style of the holotype. The molars of SIT 1253 and the M3 of SIT 1153 show many similarities with the type specimen, with the only difference being the more developed protocone and metaconule of all three molars of the specimen from Thermopigi, as well as the entostyles, which are completely absent from the holotype.

Further investigation of the above-mentioned characters in other specimens of Palaeotragus rouenii, shows that the developed lingual cone of the premolars, as well as the developed protocone and metaconule of the molars, are common characters within the taxon. The skull NHMW A476 (Kostopoulos, 2009) shows much more developed lingual cones, in both premolars and molars, than the type specimen. Additionally, the labial styles of the premolars are well pronounced. The P4 on the maxilla of the same skull bears a lingual style, which is also present in MNHN.F.PIK1670 and analogous to the well-developed cingulum of the P4 of SIT 1253. Palaeotragus rouenii from Dytiko (Geraads, 1978) reveals a developed protocone and metaconule on the molars as well as a slight lingual cingulum and a small entostyle, which is mostly prominent on the M2. Similarly, PIUW 5519 from Pikermi also displays a light cingulum and entostyle, which makes the presence of these characters relevant to the species.

The premolar length of SIT 1253 is 49.34 and the toothrow length is estimated to $123 \mathrm{~mm}$. The upper tooth row length ranges between 104-123 $\mathrm{mm}$ and the premolar length between $47-55,11 \mathrm{~mm}$ (Bohlin, 1926; Geraads, 1978; Godina, 1979; Kostopoulos and Saraç, 2005; Kostopoulos, 2009; this study). The same fluctuation for Palaeotragus microdon is $120-129 \mathrm{~mm}$ and $53-57 \mathrm{~mm}$, respectively, and for the larger $P$. coelophrys 130.71$148.4 \mathrm{~mm}$ and $57-67.09 \mathrm{~mm}$, respectively (Bohlin 1926; Geraads, 1978; this study). SIT 1253 falls within the estimated variation of Palaeotragus rouenii, with the premolar length falling in almost in the middle of the size range and the estimated toothrow length fitting close to the upper limit of the size fluctuation, very similar to the specimens from Cimislija and Akkașdağı (Godina, 1979; Kostopoulos and Saraç, 2005).

The postcranial elements do not allow major observation since most of the articular surfaces are either deformed or absent. Even though the metapodials are almost complete, the radius SIT 1256 constitutes the best-preserved postcranial element of Palaeotragus rouenii from Thermopigi.

The humerus (SIT 939) shows characters of a small giraffid. Both morphology and size resemble the humeri specimens from Samos (Kostopoulos, 2009). Similarly, the radius (SIT 1256) shows a typical large ruminant morphology. Metrically, SIT 1256 is longer than the specimens from Perivolaki (Kostopoulos and Koufos, 2006) and Samos (Kostopoulos, 2009), but also smaller in the transverse diameter of the proximal epiphysis (TDprox $=83.21$ $\mathrm{mm}$ ).

The same pattern of slenderness can be seen in the metapodials. SIT 302 is the only complete metacarpal, from which the length can be measured. It is longer than the metacarpals of $P$. rouenii from Pikermi, Kerasia and Samos, but the transverse diameter of the proximal epiphysis is very close to the one from Kerasia.

\section{Palaeotragus sp. Figure 13}

\section{Material}

Part of upper left toothrow with P2-P4 (SIT 1511), isolated right incisor i3 (SIT 1119), isolated right canine (SIT1252), left complete mandible with p2-m3 (SIT 700).

\section{Descriptions}

The presence of another small giraffid, which is different from Palaeotragus rouenii, is hereby documented and described as Palaeotragus sp. Up to the last field campaign, four specimens were recovered and attributed to this taxon. The specimens were not found attached or close to each other, but their morphology and size fulfill the assumption that SIT 1511, SIT 700, SIT 1252 and SIT 1119 belong to the same distinct taxon.

Dentition. The cranial material of Palaeotragus sp. is limited to one maxilla fragment without additional isolated teeth. SIT 1511 (Figure 13.3) represents an upper premolar toothrow, with a premolar length of $54.26 \mathrm{~mm}$. All premolars are well preserved.

The P2 is longer than the other two premolars, and it is relatively semicircular in occlusal view. The lingual cone is small, mostly pronounced towards the base of the crown and there is no cingulum. The posterolingual crista is large, bifurcated and projected lingually. The central fold is large and almost connected with the posterolabial cone. The anterior style is thin and projected labially, perpendicular to the axis of the toothrow. The anterolabial cone is well developed and parallel to the anterior 

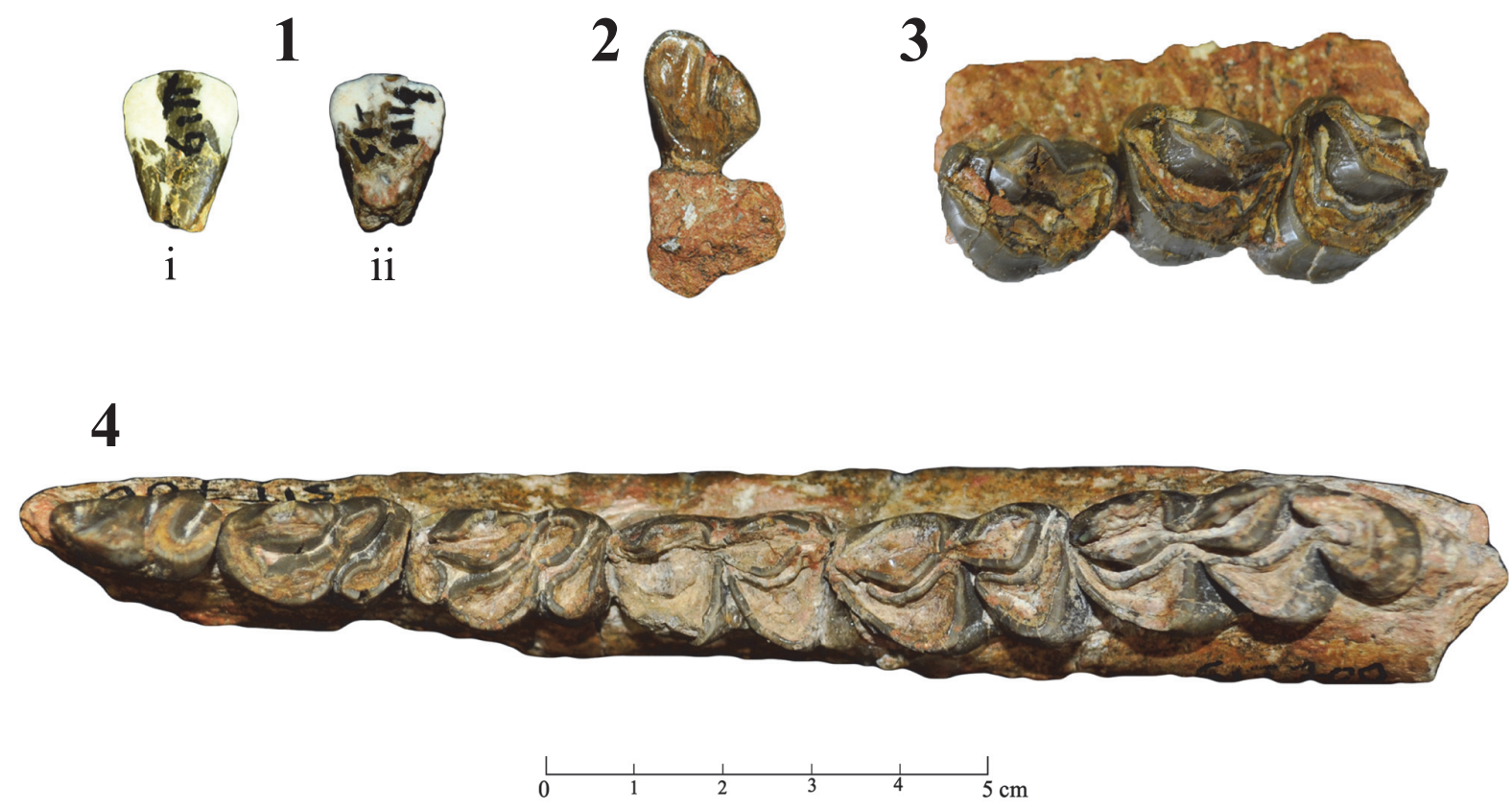

FIGURE 13. Dental fossil material of Palaeotragus sp. from Thermopigi: 1, SIT 1119, isolated right incisor i3, (i) labial view and (ii) lingual view; 2, SIT 1252, isolated right canine; 3, SIT 1511, part of upper left tooth row with p2-p4; 4, SIT 700 , left complete mandible with p2-m3. Scale equals $5 \mathrm{~cm}$.

style. The posterolabial cone is robust, leading to a slightly smaller and rounded posterolabial crista. The labial cusps are well separated by deep and open valleys. The fossa is narrow and there is no cingulum.

The P3 has a sub-rectangular shape in occlusal aspect. The posterolingual cone is well developed and, similarly to the P2, projected lingually but not bifurcated. On the level of abrasion of the tooth, the anterolingual cone is thinner but becomes very robust towards the base of the crown. At this point, a weak anterolingual cingulum can be observed. The central fold is almost as developed as in the P2. The anterior style is relatively weak and short and connected posteriorly to a very thin anterolabial crista, which opens posteriorly towards the anterolabial cone. The latter is well developed and slightly rotated anteriorly. The posterolabial cone is also strong and almost as developed as the anterolabial cone. Between them, the mesolabial crista is significantly narrow. The posterior style is more developed than the anterior one, and it gets stronger labially towards the base of the crown.

The P4 is of similar length as the other two premolars, but it is approximately $28 \%$ wider than the P2 and $22 \%$ wider than the P3. It has a trapezoid shape in occlusal view, unlike the other two premolars, which are more rounded. The lingual cone is well developed with the anterolingual crista being more robust and getting sturdier towards the base of the crown. The posterolingual crista is weak. At the base of the crown, a posterolingual cingulum can be observed, which is extended almost until the medial plane of the lingual cone. A very weak anterolingual cingulum can also be observed, right at the contact surface of P3 and $P 4$. The central fold is similar in shape to the other premolars, but it lies more anteriorly towards the center of the fossa. The latter is narrow, long and has a characteristic W-shape, due to the labial indentation of the lingual cone. The labial styles are simple and small, with the anterior style being slightly more developed than the posterior style. In occlusal aspect, they are both parallel and projected labially. The anterolabial crista is narrow, but with clear connections to the cusps on either side. The anterolabial cone is strong and slightly tilted anteriorly. The mesolabial crista is wide, making the separation of anterolabial and posterolabial cone difficult to distinguish. The latter is well defined but half the size of the anterolabial cone, 
and it reduces in size gradually towards the posterolabial crista.

The i3 (SIT 1119; Figure 13.1) is simple, with a strongly triangular shape in occlusal view. Part of the tooth was prepared with stucco, after damage subsequent to the detachment from the sediment. The base of the crown bears a strong and thick enamel layer, and the size is larger than that of $P$. rouenii.

The canine (SIT 1252; Figure 13.2) is heartshaped with the anterior lobe being just slightly longer than the posterior one. Both lobes are rounded, have approximately the same width and they are partially separated at the top of the slicing surface by a narrow groove. The proximal and the distal enamel crests of the canine converge on the bottom of the crown forming an almost right angle, giving the triangular, heart-shaped occlusal view to the tooth

SIT 700 (Figure 13.4) represents a complete left mandible with $\mathrm{p} 2-\mathrm{m} 3$. The length of the toothrow is $140.97 \mathrm{~mm}$, and the premolar row length is $58.83 \mathrm{~mm}$. The $\mathrm{p} 2$ is triangular. The anterior stylid is thin, and the anterior conid is absent, revealing an open anterior valley. The mesolingual conid is weak and simple, without a distinct anterolingual or posterolingual cristid. The posterior valley is more closed, because of the relatively robust posterolingual conid. The latter has the same size as the posterior stylid, and the valley between them is oval shaped and narrow. The mesolingual conid, the posterolingual conid and the posterior stylid are parallel to each other, creating an $80^{\circ}$ angle with the axis of the toothrow. The posterolabial and mesolabial conid are simple.

On the p3 the mesolingual conid is connected via a thick crest with the anterior conid. This crest keeps running through the mesolabial conid to the posterolingual conid where it ends. The posterior stylid and posterolabial conid are connected and isolated from the rest of the cusps through a wide posterior valley. This valley runs through the whole tooth, until it cuts the labial surface open. The anterior conid is well developed and lacks an anterior stylid. The mesolingual conid is rather weak. The posterolingual cristid ends into a rounded apex, while the anterolingual cristid gets wider, until it meets the well-developed anterior conid. The posterolabial conid is also rather robust.

The p4 is separated into three rather elongated cusp groups. The anterior conid and the mesolingual conid cover the proximal part of the tooth. The posterior valley separates those cusps from the posterolingual and mesolabial conid, and the back valley leave the posterior stylid and the posterolabial conid isolated. The mesolingual conid is large and connected with the robust anterior conid, which is completely isolated from the labial cusps. These two conids are connected, closing the anterior valley and they are perpendicular to each other. The anterolabial cristid is connected to the posterolingual conid through the well-developed mesolabial conid. The group of posterior stylid and posterolabial conid is very similar to the p3, with the posterolabial conid being notably bigger.

The $\mathrm{m} 1$ is simple, with the anterior lobe being slightly larger than the posterior lobe. The anterior part of the protoconid and the posterior part of the hypoconid are lacking. Lingually, there are no cristids or stylids, while labially the ectostylid is very small and rounded.

The $\mathrm{m} 2$ display the same morphology as the $\mathrm{m} 1$. The metaconid is well developed and the anterior cingulum is weak. There is no ectostylid, and the lingual side is smooth.

The $\mathrm{m} 3$ is rather large with robust cusps. The protoconid is robust and slightly larger than the hypoconid. Metaconid and entoconid show the same size. The hypoconulid is also strong and the entoconulid is not connected with the entoconid. Instead the preentoconulidcristid ends up in a pointed apex, which is situated anterolingually.

\section{Comparisons}

The above-described material is not sufficient to provide a clear species determination. However, it is unambiguous, that these dental elements belong to a small- to medium-sized giraffid. Taking the overall morphology into consideration the specimens are assigned to the genus Palaeotragus.

SIT 1511 has a premolar length of $54.26 \mathrm{~mm}$. The same range for Palaeotragus rouenii, P. microdon and $P$. coelophrys is $47-55.11 \mathrm{~mm}, 53-57 \mathrm{~mm}$ and 57-67.09 mm, respectively. SIT 1511 falls between $P$. rouenii and $P$. microdon, but also very close to $P$. pavlowae from Hrebenyky, Ukraine. $P$. coelophrys, $P$. berislavicus and $P$. asiaticus show higher values of upper premolar length (Figure 14). Additionally, the P2 of SIT 1511 is long and narrow, an interesting morphology which is also present in $P$. coelophrys from Maragheh (plate I, figure 2 in Rodler and Weithofer, 1890).

Lower canines from fossil giraffids are not abundant. The lower canine from Thermopigi (SIT 1252), shows significant differences compared to canines of other palaeotragine species. The canine is larger than the one of Palaeotragus rouenii 


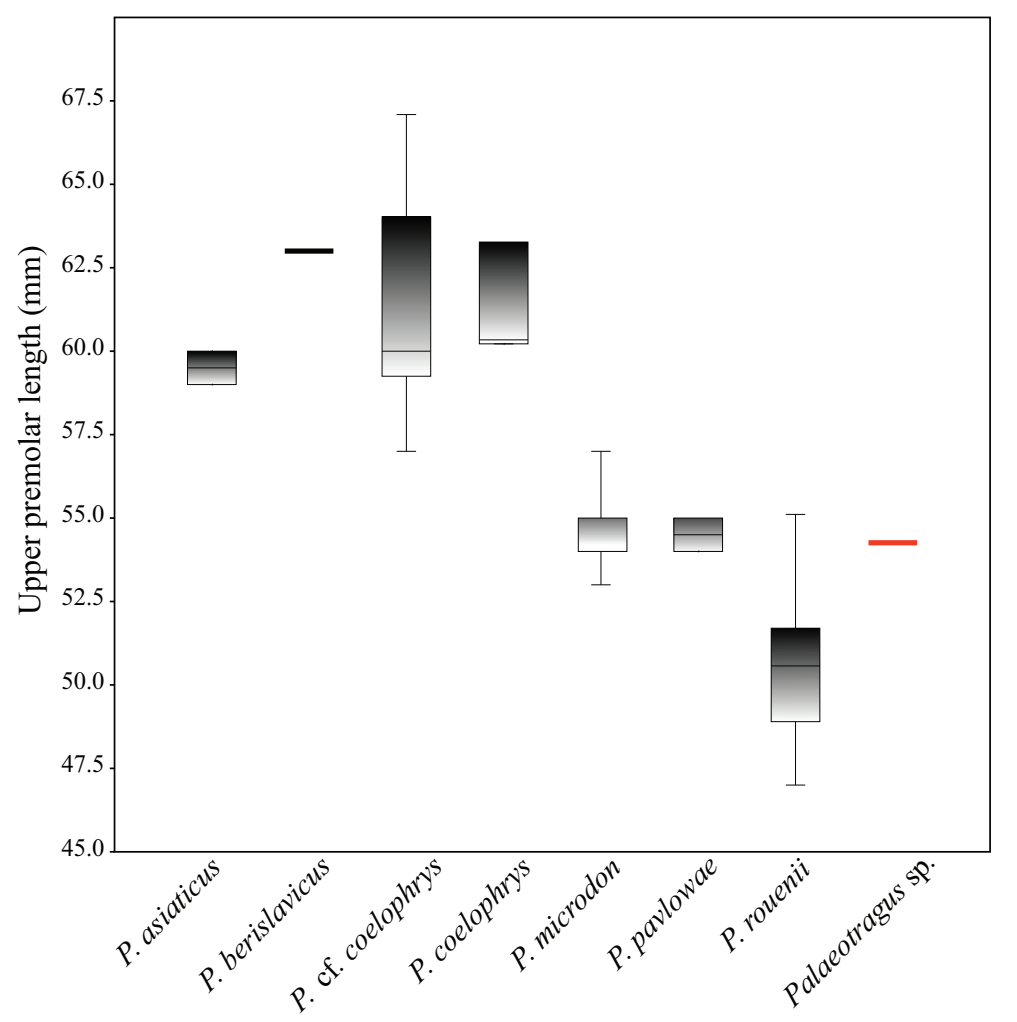

FIGURE 14. Box plot of average amount of upper premolar length of various Palaeotragus species. The red line represents the measurement of the Thermopigi specimen. Each box represents $50 \%$ of the range of the premolar length, while the top and the bottom bars represent the overall range of the length. The vertical line in the center of each box represents the median of the sample (data from Bohlin, 1926; Korotkevich, 1970; Geraads, 1978; Godina, 1979; Krakhmalnaya, 1996; Kostopoulos and Saraç, 2005; Kostopoulos, 2009; this study).

(DIT2; Geraads, 1978) and smaller than P.coelophrys (NHMW No.17; Rodler and Weithofer, 1890). In Samotherium, the canines are more shovel-like and palmate than the ones of Palaeotragus.

Incisors are also very scarce. SIT 1119 and DIT2 (Geraads, 1978) show a simple and clear triangular shape in occlusal view, but with the latter being $42 \%$ smaller in crown height and 20\% smaller in the length of the slicing surface. The i3 of Palaeotragus coelophrys from Maragheh (plate IV, figure 4 in Rodler and Weithofer, 1890) shows a more complex morphology, with the proximal crest being lower than the distal one. In Samotherium major from Vathylakkos (VAT 157; plate I, figure 5 in Geraads, 1978), Samos (PIUW 3831-20) and Alcicephalus neumayri from Maragheh (plate IV, figure 2 in Rodler and Weithofer, 1890), the incisors, alike the canines, are more shovel like and palmate in occlusal aspect. Therefore, the morphology of SIT 1119 suggests including the specimen in the genus Palaeotragus. Furthermore, the size, as well as the strong enamel wall, which can be observed at the base of the crown, suggests that SIT 1119 belongs to a Palaeotragus taxon larger than $P$. rouenii.

SIT 700, has a toothrow length of $140.97 \mathrm{~mm}$ and a premolar length of $58.83 \mathrm{~mm}$. The same range of Palaeotragus rouenii is $126-136.1 \mathrm{~mm}$ and of $P$. microdon is $130-136 \mathrm{~mm}$. The premolar length fluctuation for $P$. rouenii and $P$. microdon is 46.5-55.5 mm and 47-60 mm, respectively, showing a large metrical overlapping (Figure 15). Palaeotragus sp. is at the upper end of the metrical distribution of $P$. rouenii. However, the premolar morphology differs from the fluctuation found within $P$. rouenii, while it is very similar to Palaeotragus sp. from Kerasia (lliopoulos, 2003). Thus, the morphometrical dental data also suggest that the Palaeotragus sp. material from Thermopigi belong to a larger-sized, Palaeotragus and not $P$. rouenii.

\section{BIOCHRONOLOGY AND CONCLUSIONS}

Up until now, the only taxonomic study on the palaeofauna from Thermopigi focused on the collection of Chalicotheriidae (Geraads et al., 2007). 


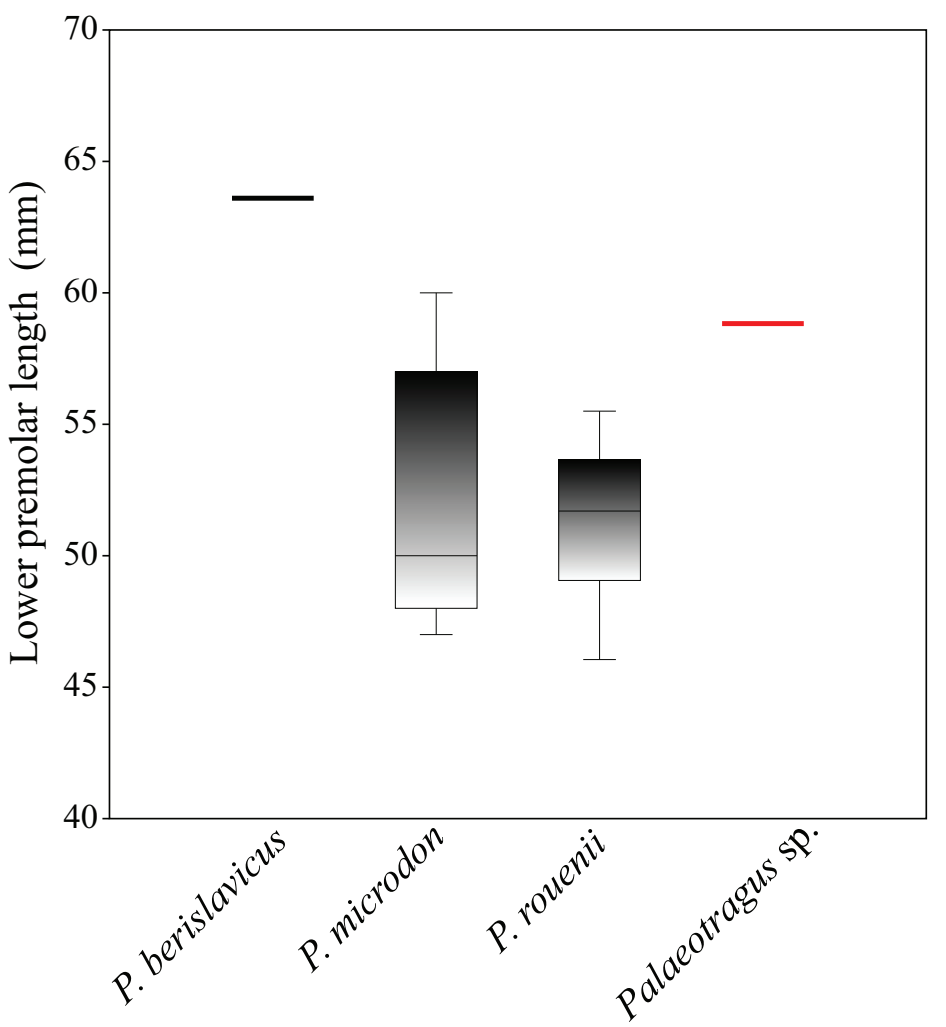

FIGURE 15. Box plot of lower premolar length of various Palaeotragus taxa. The red line represents the measurement of the Thermopigi specimen. Each box represents $50 \%$ of the range of the premolar length. The top and the bottom bars represent the overall range of the length. The vertical line in the center of each box represents the median of the sample (data from Schlosser, 1924; Bohlin, 1926; Korotkevich, 1970; Geraads, 1978; Godina, 1979; Iliopoulos, 2003; Kostopoulos and Saraç, 2005; this study).

Therefore, further studies on the fauna are essential to enable meaningful comparisons with other late Miocene terrestrial vertebrate localities. The fossils collected at Thermopigi all originate from the same fossiliferous horizon. The co-occurrence of the different giraffid species presented here gives an insight into the biochronology of Thermopigi. In total, four species have been identified: Helladotherium duvernoyi, Samotherium major, Palaeotragus rouenii and Palaeotragus sp.

Helladotherium duvernoyi has a wide chronological distribution, which ranges from late Vallesian to late Turolian, with the first occurrence of the species coming from the late Vallesian of Nikiti (Kostopoulos et al., 1996; Kostopoulos and Koufos, 2006; Kostopoulos, 2009; Koufos et al., 2009). This species is also present at Pikermi (Gaudry, 1861; Melentis. 1974; Solounias. 1981a; Solounias. 1981b), Samos (Forsyth-Major, 1888; Solounias. 1981b; Kostopoulos, 2009), Kerasia (lliopoulos, 2003), Perivolaki (Kostopoulos and Koufos, 2006), Akkaşdağı (Kostopoulos and Saraç, 2005), Kalimantsi-Hadjidimovo (Geraads et al., 2005) and Mont Luberon (Gaudry, 1873). Since it has been documented that $H$. duvernoyi gets increasingly abundant in the upper part of the middle Turolian (Kostopoulos and Koufos. 2006; Koufos et al., 2009; Kostopoulos, 2009), its dominance at Thermopigi might indicate a similar age. Samotherium major is known from Samos (Forsyth-Major, 1888; Bohlin, 1926; Kostopoulos, 2009), Vathylakkos (Geraads, 1978), Kerasia (lliopoulos, 2003), Kemiklitepe A/B (Geraads, 1994), Akkaşdağı (Kostopoulos and Saraç, 2005), Taşkinpaşa (Şenyürek, 1954), Mahmutgazi (Geraads, 2017) and Maragheh (Solounias and Danowitz, 2016a). This species generally indicates a middle Turolian age and is considered to have replaced its ancestor, $S$. boissieri, at about 7.4 m.y.a. at the transition of the MN11-MN12 zones (Kostopoulos et al., 2003; Kostopoulos, 2009). Palaeotragus rouenii has a chronostratigraphic distribution that ranges from late Vallesian (MN10) to late Turolian (MN 13) (Gentry et al., 1999; Koufos et al., 2009; Kostopoulos, 2009). According to Koufos et al. (2009), the coexistence of $P$. rouenii 
alongside a more robust palaeotragine, suggests an early Turolian age (MN11). The authors note that it is very uncommon for a larger species of Palaeotragus to appear in middle Turolian assemblages. However, it is pointed out that $P$. rouenii was coexisting with the larger Palaeotragus sp. and Samotherium major from the MTLB horizon, with the latter clearly suggesting a middle Turolian age.

A big part of the associated fauna is currently under study. Geraads et al. (2007) described Ancylotherium pentelicum Gaudry and Lartet (1856) from Thermopigi and assumed it was of Turolian age, without being more specific since the taxon has a wide chronological distribution. However, Koufos et al. (2009) reported that this rare taxon suggests a middle Turolian age. Recently, Kostopoulos and Soubise (2018) described Palaeoreas lindermayeri Wagner (1848) from Thermopigi, which also has a wide distribution, spanning from early to late Turolian. In addition, the study of the Rhinocerotidae assemblage from Thermopigi revealed the presence of Dihoplus pikermiensis Toula (1906) (Tsoukala, 2018), which has also been reported from Pikermi, Samos and Middle Sinap (Heissig, 1996; Fortelius et al., 2003; Giaourtsakis, 2009). The co-existance of D. pikermiensis with "Diceros" neumayri Osborn (1900) and Ancylotherium pentelicum indicates a middle Turolian age (Koufos et al., 2009). "Diceros" neumayri is not present at Thermopigi. However, the taxon constitutes a chronologically wide-spread species, spanning from MN9 to MN12 (Heissig, 1975; Giaourtsakis, 2009). Proboscidea represented by few post cranial elements of Deinotheriidae and Elephantimorpha that are due to the absence of dental material and the high degree of deformation, not suitable for further taxonomic classification (Konidaris and Tsoukala, in press). Suidae are represented by Propotamochoerus aegaeus Lazaridis (2015) and Hippopotamodon major Gervais (1848-1852) (Geraads, 2007; Lazaridis, personal commun., 2018). The first is known from the late Miocene of Greece, FYR Macedonia and Bulgaria, with a chronostratigraphic distribution covering the whole Turolian, from MN11 to MN13 (Lazaridis, 2015). Hippopotamodon major is recorded from 68 localities across Eurasia, with a very wide chronostratigraphic distribution (The NOW Community, 2016). The equids consti- tute the most abundant group at Thermopigi and they are currently under study. Preliminary results reveal the presence of four co-occuring taxa, two large-sized, one medium-sized and one smallsized hipparionine (Lazaridis, personal commun., 2018). The largest shows many similarities with Hippotherium brachypus Hensel (1862), which is known from MN12 of Southeast Mediterranean (Koufos et al., 2009).

According to the above-mentioned data and taking into consideration the abundance of Helladotherium duvernoyi, the presence of Samotherium major and moreover the coexistence of the latter with Palaeotragus rouenii and a slightly larger palaeotragine (Palaeotragus sp.), it is concluded that the fauna from Thermopigi is of middle Turolian age (MN12) (Figure 16).

\section{ACKNOWLEDGEMENTS}

For access to the material and comparative collections we want to thank G. Koufos and D. Kostopoulos (AUTH), S. Roussiakis (National and Kapodistrian University of Athens), $\mathrm{O}$. Hampe and T. Schossleitner (Museum für Naturkunde, Berlin), U. Göhlich (NHMW) and G. Rössner (Bayerische Staatssammling für Paläontologie und Geologie). For their help and guidance with the preparation of the fossils, V. Perlinger, F. Meyer and R. Meyer (PIUW) are thanked. We would also like to thank W. Eder (PIUW) for his assistance in the collection of the stratigraphic data. For their special guidance and supply with important information we thank $D$. Kostopoulos, G. Lazaridis (AUTH), M. Tranos (AUTH), S. Roussiakis and G. Iliopoulos (University of Patras). Special thanks to M. Michail (Università degli studi di Ferrara) for her assistance with the construction of the map of the study area. Additionally, we would like to thank the local authorities for supporting the excavation team since the beginning of the field work. We owe thanks to the handling editor Dr. A. Souron, as well as to the executive editors for their assistance in the submission and review of the manuscript. We also kindly acknowledge the three anonymous reviewers for the comments and remarks, which considerably helped improving this publication. This study was funded by the Austrian Science Fund (FWF) (project number P29501-B25) with grant to A.X. and F.G. 


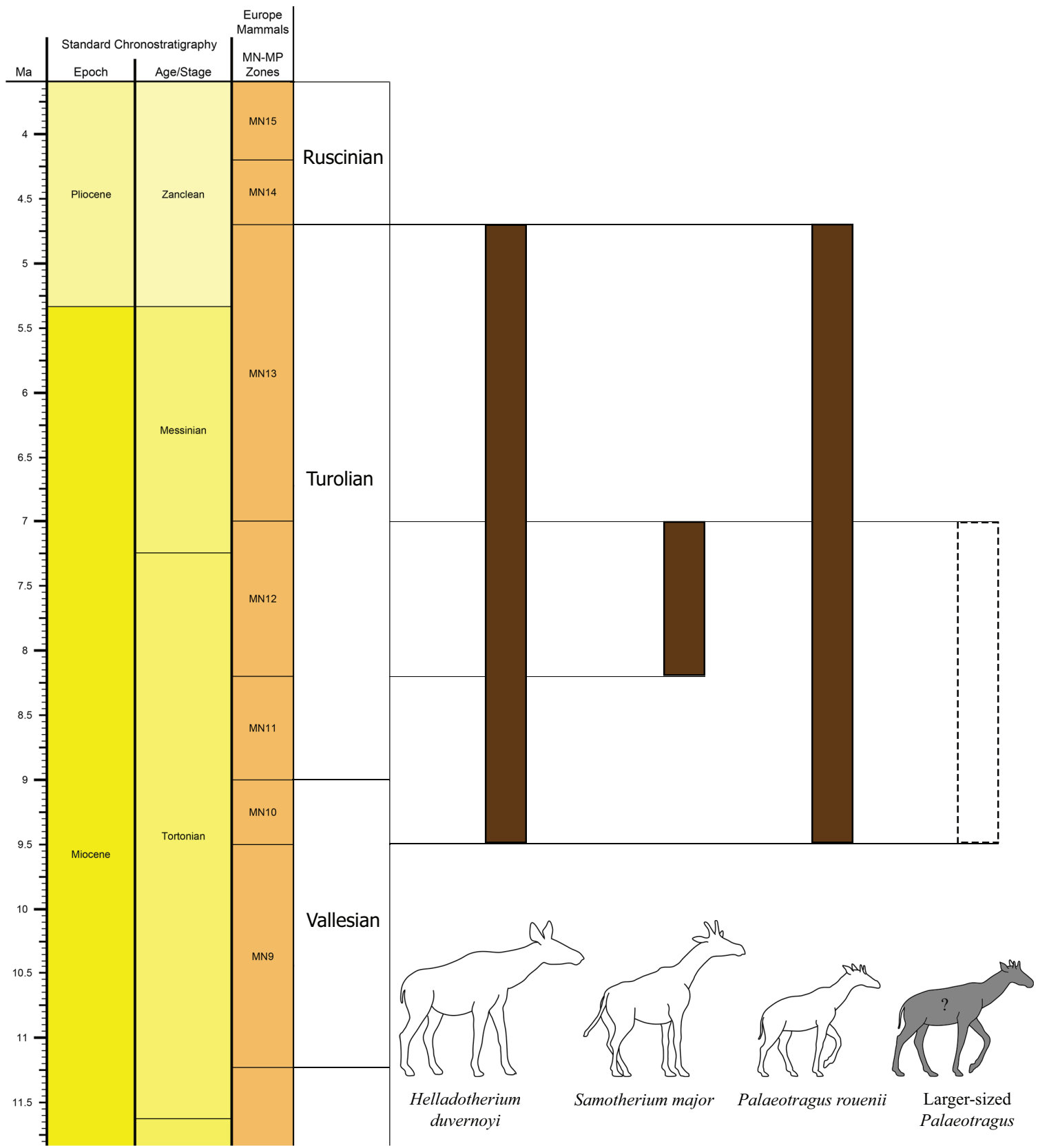

FIGURE 16. Chronostratigraphic distribution of the giraffid species found at Thermopigi: Helladotherium duvernoyi, Samotherium major, Palaeotragus rouenii and Palaeotragus sp. (data from Steininger, 1999; lliopoulos, 2003; Koufos, 2006; Kostopoulos, 2009; Koufos et al., 2009).

\section{REFERENCES}

Alexeiev, A. 1916. Animaux fossiles du Village Novo-Elisavetovka Odessa. Typographia

"Tiechnek" lekaterenenskaya, Odessa. (In Russian with French abstract)

Alexeiev, A. 1930. Die obersarmatische Fauna von Eldar. Travaux du Musée Géologique près

l'Académie des Sciences de l'URSS, 8:167-204. (In Russian with German abstract) 
Arambourg, C. 1963. Continental vertebrate faunas of the Tertiary of North Africa, p. 56-63. In Howell, F.C. and Bourlière, F. (ed.), African Ecology and Human Evolution. Aldine Publication Co., Chicago.

Athanassiou, A. 2002. Neogene and Quaternary mammal faunas of Thessaly. Annales Géologiques des Pays Helléniques, 39(A):279-293.

Athanassiou, A. 2014. New giraffid (Artiodactyla) material from the Lower Pleistocene locality of Sésklo (SE Thessaly, Greece): Evidence for an extension of the genus Palaeotragus into the Pleistocene. Zitteliana B, 32:71-89.

Bakalov, P., Nikolov, I.V., and Tzankov, V. 1962. Les Fossiles de Bulgarie. X. Mammifères Tertiaires. Académie des Sciences de Bulgarie, Sofia. (In Bulgarian with French abstract)

Bärmann, E.V. and Rössner, G.E. 2011. Dental nomenclature in Ruminantia: Towards a standard terminological framework. Mammalian Biology-Zeitschrift für Säugetierkunde, 76(6):762-768. https://doi.org/10.1016/j.mambio.2011.07.002

Bohlin, B. 1926. Die Familie Giraffidae mit besonderen Berucksichtgungder fossilen Formen aus China. Palaeontologia Sinica, ser C, 4.

Bonis, L.D. and Bouvrain, G. 2003. Nouveaux Giraffidae du Miocène supérieur de Macédoine (Grèce), p. 5-16. In Petculescu, A. and Stiuca, E. (ed.), Advances in Vertebrate Paleontology "Hen to Panta". Romanian Academy, Bucharest.

Bonis, L.D., Bouvrain, G., Geraads, D., and Koufos, G. 1992. Diversity and paleoecology of Greek late Miocene mammalian faunas. Palaeogeography, Palaeoclimatology, Palaeoecology, 91(1-2):99-121. https://doi.org/10.1016/0031-0182(92)90035-4

Bonis, L.D., Koufos, G.D., and Sen, S. 1997. A giraffid from the Middle Miocene of the island of Chios, Greece. Palaeontology, 40:121-134.

Borissiak, A. 1914. Mammifères fossiles de Sébastopol II. Mémoires du comité Géologique, Nouvelle série, Livraison 137, Paris.

Churcher, C.S. 1970. Two new upper Miocene giraffids from Fort Ternan, Kenya, East Africa: Palaeotragus primaevus n. sp. and Samotherium africanum n. sp. Fossil Vertebrates of Africa, 2:1-106.

Churcher, C.S. 1978. Giraffidae, p. 509-535. In Maglio, V.J. and Cooke, H.B.S. (ed.), Evolution of African Mammals. Harvard University Press, Cambridge, Massachusetts, United States. https://doi.org/10.4159/harvard.9780674431263.c26

Forsyth-Major, C.J. 1888. Sur un gisement d'ossements fossiles dans l'île de Samos contemporains de l'âge de Pikermi. Compte Rendus Hebdomadaire, Séances de la Société Géologique de France, 107:1178-1181. https://doi.org/10.1017/S0016756800189356

Forsyth-Major, C.J. 1891. On the fossil remains of species of the family Giraffidae. Proceedings of the Zoological Society of London, 59:315-326. https://doi.org/10.1111/j.10963642.1891.tb01755.x

Fortelius, M., Heissig, K., Saraç, G., and Sen, S. 2003. Rhinocerotidae (Perissodactyla), p. 282307. In Fortelius, M., Kappelman, J., Sen, S., and Bernor, R.L. (ed.), Geology and Paleontology of the Miocene Sinap Formation, Turkey. Columbia University Press, New York.

Gaudry, A. 1860. Resultats des fouilles executees en Grece sous les auspices de l' Academie. Comptes Rendus de l'Academie des Sciences, 51:802-804.

Gaudry, A. 1861. Note sur la giraffe et l' Helladotherium trouvees a Pikermi (Grece). Bulletin de la Societee Geologique de France, 2eme serie, 5: 587-597.

Gaudry, A. 1862-67. Animaux Fossiles et Géologie de l'Attique. Recherches faites en 18551856, 1860. Savy F., Paris.

Gaudry, A. 1873. Animaux Fossiles du Mont Léberon (Vaucluse): Etude sur les Vertébrés. Savy F., Paris.

Gaudry, A. and Lartet, E. 1856. Résultats des recherches paléontologiques entreprises dans l'Attique sous les auspices de l'Académie. Compte Rendu des Séances de l'Académie des Sciences, 43:271-274.

Gentry, A.W. 2003. Ruminantia (Artiodactyla), p. 332-379. In Fortelius, M., Kappelman, J., Sen, S., Bernor, R.L. (ed.), Geology and Paleontology of the Miocene Sinap Formation, Turkey. Columbia University Press, New York.

Gentry, A.W. and Heizmann, E.P.J., 1996. Miocene Ruminants of the central and eastern Tethys and Paratethys, p. 378-391. In Bernor, R.L., Fahlbusch, V., and Mittmann, H.W. (ed.), The Evolution of Western Eurasian Neogene Mammal Faunas. Columbia University Press, New York. 
Gentry, A.W., Rössner, G.E., and Heizmann, E.P.J. 1999. Suborder Ruminantia, p. 225-253. In Rössner, G.E. and Heissig, K. (ed.), The Miocene Land Mammals of Europe. Verlag Dr. Friedrich Pfeil, Munich.

Geraads, D. 1974. Les Giraffidés du Miocène Supérieur de la Région de Thessalonique (Grèce). Unpublished PhD Thesis, University of Paris, France.

Geraads, D. 1978. Les Palaeotraginae (Giraffidae, Mammalia) du Miocene superieur de la region de Thessalonique (Grece). Géologie Méditerranéenne, 5(2):269-276.

Geraads, D. 1986. Remarques sur la systématique et la phylogénie des Giraffidae (Artiodactyla, Mammalia). Geobios, 19(4):465-477. https://doi.org/10.1016/s0016-6995(86)80004-3

Geraads, D. 1994. Les gisements de mammifères du Miocène supérieur de Kemiklitepe, Turquie. VIII: Giraffidae. Bulletin du Muséum National d'Histoire Naturelle. Section C, Sciences de la Terre, Paléontologie, Géologie, Minéralogie, 16(1):159-173.

Geraads, D. 2009. Giraffidae (Mammalia) de la fin du Néogène de la République de Macédoine (ARYM). Geodiversitas, 31(4):893-908. https://doi.org/10.5252/g2009n4a893

Geraads, D. 2017. Late Miocene large mammals from Mahmutgazi, Denizli province, Western Turkey. Neues Jahrbuch für Geologie und Paläontologie-Abhandlungen, 284(3):241-257. https://doi.org/10.1127/njgpa/2017/0661

Geraads, D. and Güleç, E. 1999. On some spiral-horned antelopes (Mammalia: Artiodactyla: Bovidae) from the Late Miocene of Turkey, with remarks on their distribution. Paläontologische Zeitschrift, 73(3-4):403-409. https://doi.org/10.1007/bf02988051

Geraads, D., Spassov, N., and Kovachev, D. 2005. Giraffidae (Artiodactyla, Mammalia) from the Late Miocene of Kalimantsi and Hadjidimovo, Southwestern Bulgaria. Geologica Balcanica, 35(1-2):11-18.

Geraads, D., Tsoukala, E., and Spassov, N. 2007. A skull of Ancylotherium (Chalicotheriidae, Mammalia) from the late Miocene of Thermopigi (Serres, N. Greece) and the relationships of the genus. Journal of Vertebrate Paleontology, 27(2):461-466. https://doi.org/10.1671/02724634(2007)27[461:asoacm]2.0.co;2

Gervais P. 1848-1852. Zoologie et Paléontologie Francaises. A. Bertrand, Paris, 2 vols, 3 vols.

Giaourtsakis, I.X. 2009. The Late Miocene mammal fauna of the Mytilinii Basin, Samos Island, Greece: New Collection 9. Rhinocerotidae. Beiträge zur Paläontologie, 31:157-187.

Godina, A.Y. 1979. History of Fossil Giraffes of the Genus Palaeotragus. Trudy. Paleontological Institut Akademia Nauk USSR, Vol. 177. (In Russian)

Godina, A.Y. 2002. On the taxonomy and evolution of Samotherium (Giraffidae, Artiodactyla). Paleontological Journal, Moscow, 36:395-402.

Gray, J.E. 1821. On the natural arrangement of vertebrose animals. London Medical Repository, 15:297-310

Grossman, A. and Solounias, N. 2014. New fossils of Giraffoidea (Mammalia: Artiodactyla) from the Lothidok Formation (Kalodirr Member, Early Miocene, West Turkana, Kenya) contribute to our understanding of early giraffoid diversity. Zitteliana $B, 32: 63-70$. https://doi.org/ 10.5282/ubm/epub.22387

Hamilton, W.R. 1973. The lower Miocene ruminants of Gebel Zelten, Libya. Bulletin of the British Museum of Natural History (Geology), 21(3):73-150.

Hamilton, W.R. 1978. Fossil giraffes from the Miocene of Africa and a revision of the phylogeny of the Giraffoidea. Philosophical Transactions of the Royal Society of London B: Biological Sciences, 283(996):165-229. https://doi.org/10.1098/rstb.1978.0019

Hammer, Ø., Harper, D.A.T., and Ryan, P.D. 2001. PAST: Palaeontological statistics software package for education and data analysis. Palaeontologia Electronica 4.1.4A:9p. http://palaeo-electronica.org/2001_1/past/past.pdf

Harris, J., Solounias, N., and Geraads, D. 2010. Giraffoidea, p. 797-811. In Werdelin, L. and Sanders, W.J. (ed.), Cenozoic Mammals of Africa. University of California Press, Berkley. https://doi.org/10.1525/california/9780520257214.003.0039

Heintz, E., Brunet, M., and Sen, S. 1981. Un nouveau giraffide du Miocene superieur d'Irak: Injanatherium hazimi n. g., n. sp. Comptes Rendus de l'Académie des Sciences Serie II, Sciences de la Vie, 292:423-426.

Heissig, K. 1975. Rhinocerotidae aus dem Jungtertiär Anatoliens. Geologisches Jahrbuch (B), 15:145-151. 
Heissig, K. 1996 The stratigraphical range of fossil rhinoceroses in the Late Neogene of Europe and Eastern Mediterranean p. 339-347. In Bernor, R.L., Fahlbusch, V., and Mittmann, H.W. (ed.), The Evolution of Western Eurasian Neogene Mammal Faunas. Columbia University Press, New York.

Hensel, R. 1862. Über die Reste einiger Säugetierarten von Pikermi in der Münchener Sammlung. Monatsberichte der Akademie der Wissenschaften, 27:560-569.

Hou, S., Danowitz, M., Sammis, J., and Solounias, N. 2014. Dead ossicones, and other characters describing Palaeotraginae (Giraffidae; Mammalia) based on new material from Gansu, Central China. Zitteliana B, 32:91-98. https://doi.org/10.5282/ubm/epub.22389

Iliopoulos, G. 2003. The Giraffidae (Mammalia, Artiodactyla) and the Study of the Histology and Chemistry of Fossil Mammal Bone from the Late Miocene of Kerassia (Euboea Island, Greece). Unpublished PhD Thesis, University of Leicester, UK. http://hdl.handle.net/2381/ 35044

Janis, C.M. 1987. Grades and clades in hornless ruminant evolution: the reality of the Gelocidae and the systematic position of Lophiomeryx and Bachitherium. Journal of Vertebrate Paleontology, 7(2):200-216. https://doi.org/10.1080/02724634.1987.10011653

Janis, C.M. and Scott, K.M. 1987. The interrelationships of higher ruminant families: with special emphasis on the members of the Cervoidea. American Museum Novitates, 2893:1-85.

Karadenizli, L., Seyitoğlu, G., Sen, S., Arnaud, N., Kazancı, N., Saraç, G., and Alçiçek, C. 2005. Mammal bearing late Miocene tuffs of the Akkasdagi region; Distribution, age, petrographical and geochemical characteristics, p. 553-566. In Sen, S. (ed.), Geology, Mammals and Environments at Akkaşdağı, Late Miocene of Central Anatolia. Geodiversitas 27.

Karydakis, G., Arvanitis, A., Andritsos, N., and Fytikas, M. 2005. Low enthalpy geothermal fields in the Strymon Basin (Northern Greece). Proceedings of the World Geothermal Congress 2005, Antalya, Turkey, p. 24-29.

Kockel, F. and Walther, H.W. 1965. Die Strimonlinie als Grenze zwischen Serbo-Mazedonischem und Rila-Rhodope-Massiv in Ost-Mazedonien. Geologisches Jahrbuch, 83:575-602.

Koken, E. 1885. Über fossile Säugethiere aus China. Palaeontologische Abhandlungen, 3:31113.

Konidaris G.E., Tsoukala, E. in press. Proboscideans from the upper Miocene localities of Thermopigi, Neokaisareia and Platania (Northern Greece). Annales de Paléontologie.

Korotkevich, E.L. 1970. Mlekopitajushchie berislavskoj pozdnesarmatskoj gipparionovoj fauny. Prirodnaja Obstanovka i Fauny Prošlogo, 5:24-121. (In Russian)

Korotkevich, E.L. 1978. New species of Samotherium from the Meotian of the North Black Sea Area. Vestnik Zoologii, Institute of Technology, Academy of Sciences, Kiev, 4:9-18. (In Russian)

Kostopoulos, D.S. 1996. The Plio-Pleistocene Artiodactyls of Macedonia (N. Greece). Systematics, Palaeoecology, Biochronology, Biostratigraphy. Unpublished PhD Thesis, Aristotle University of Thessaloniki. (In Greek with English summary)

Kostopoulos, D.S. 2009. The late Miocene mammal faunas of the Mytilinii Basin, Samos Island, Greece: new collection: 13. Giraffidae, p. 299-343. In Koufos G.D. and Nagel D. (ed.), The Late Miocene Mammal Faunas of Samos. Beiträge zur Paläontologie, 31, Vienna, Austria.

Kostopoulos, D.S. 2016. Artiodactyla. Geobios 49(1-2):119-134. https://doi.org/10.1016/j. geobios.2016.01.011

Kostopoulos, D.S, and Koufos, G.D. 2006. The late Miocene vertebrate locality of Perivolaki, Thessaly, Greece. 8. Giraffidae. Palaeontographica Abteilung A, 276(1-6):135-149.

Kostopoulos, D.S. and Saraç, G. 2005. Giraffidae (Mammalia, Artiodactyla) from the late Miocene of Akkaşdağı, Turkey, p. 735-745. In Sen, S. (ed.), Geology, Mammals and Environments at Akkaşdağı, late Miocene of Central Anatolia. Geodiversitas 27.

Kostopoulos, D.S. and Sen, S. 2016. Suidae, Tragulidae, Giraffidae, and Bovidae. Geodiversitas, 38(2):273-298. https://doi.org/10.5252/g2016n2a8

Kostopoulos, D.S. and Soubise, J. 2018. Palaeoreas, Majoreas, and Stryfnotherium gen. nov. (Mammalia: Artiodactyla: Bovidae) from the Late Miocene of Greece. Annales de Paléontologie, 104(3):231-247. https://doi.org/10.1016/j.annpal.2018.04.002

Kostopoulos, D.S., Koliadimou, K.K., and Koufos, G.D. 1996. The giraffids (Mammalia, Artiodactyla) from the late Miocene mammalian localities of Nikiti (Macedonia, Greece). Palaeontographica Abteilung A, 239(1-3):61-88. 
Kostopoulos, D.S., Sen, S., and Koufos, G.D. 2003. Magnetostratigraphy and revised chronology of the late Miocene mammal localities of Samos, Greece. International Journal of Earth Sciences, 92(5):779-794. https://doi.org/10.1007/s00531-003-0353-8

Koufos, G.D. 2006. The Neogene mammal localities of Greece: faunas, chronology and biostratigraphy. Hellenic Journal of Geosciences, 41(1):183-214.

Koufos, G.D., Kostopoulos, D.S., and Vlachou, T.D. 2009. The late Miocene mammal faunas of the Mytilinii basin, Samos Island, Greece: new collection. 16. Biochronology, p. 397-408. In Koufos, G.D., and Nagel, D. (ed.), The late Miocene Mammal Faunas of Samos. Beiträge zur Paläontologie, 31, Vienna, Austria.

Krakhmalnaya, T.V. 1996. The Hipparion Fauna from the Meotian of the Northern Part of the Black Sea Region. Naukova Dumka, Kiev. (In Russian).

Lazaridis, G. 2015. Study of the Late Miocene Vertebrate Locality of Kryopigi and Other Localities of Kassandra Peninsula, Chalkidiki (Greece). Systematics, Taphonomy, Paleoecology, Biochronology. PhD Thesis, Aristotle University of Thessaloniki, Scientific Annals of the School of Geology, 174:350. Greece. (In Greek with English abstract)

Linnaeus, C. 1758. Systema Naturae. Volume 1 (tenth edition). Engelman, Leipzig.

Marinos, G. and Symeonidis, N. 1974. Neue Funde aus Pikermi (Attika, Griechenland) und eine allgemeine geologische Übersicht dieses paläontologischen Raumes. Annales Geologique des Pays Hellenique, 26:1-20.

Melentis, I.K. 1974. Helladotherium duvernoyi Gaudry, 1860 aus Pikermi (Griechenland). Scientific Epetiris: Issued by the Faculty of Natural and Mathematical Sciences (AUTH), 14:65-73.

Mitchell, G. and Skinner, J.D. 2003. On the origin, evolution and phylogeny of giraffes Giraffa camelopardalis. Transactions of the Royal Society of South Africa, 58(1):51-73. https:// doi.org/10.1080/00359190309519935

Osborn, H.F. 1900. Phylogeny of the rhinoceroses of Europe. Bulletin of the American Museum of Natural History, 13:229-267.

Owen, R. 1848. Description of teeth and portions of jaws of two extinct anthracotherioid quadrupeds (Hyopotamus vectianus and Hyop. bovinus) discovered by the Marchioness of Hastings in the Eocene deposits on the N.W. coast of the Isle of Wight: with an attempt to develop Cuvier's idea of the classification of pachyderms by the number of their toes. Quarterly Journal of the Geological Society of London, 4:103-141. https://doi.org/10.1144/ gsl.jgs.1848.004.01-02.21

Ozansoy, F. 1965. Etudes des gisements continentaux et des mammifères du Cénozoïque de Turquie. Au Siège de la Société Géologique, 102:1-92

Paraskevaidis, I. 1940. Eine obermiocöne Fauna von Chios. Neues Jahrbuch für Mineralogie, Geologie und Pläontologie, Abteilung B, 83:363-442.

Pilgrim, G.E. 1910. Notices of new mammalian genera and species from the Tertiaries of India. Records of the Geological Survey of India, 40:63-71.

Pilgrim, G.E. 1911. The fossil Giraffidae of India. Memoirs of the Geological Survey of India, 4:129.

Psilovikos, A. and Karistineos, N. 1986. A depositional sedimentary model for the Neogene uraniferous lignites of the Serres Graben, Greece. Palaeogeography, Palaeoclimatology, Palaeoecology, 56(1-2):1-16. https://doi.org/10.1016/0031-0182(86)90104-5

Ríos, M., Danowitz, M., and Solounias, N. 2016. First comprehensive morphological analysis on the metapodials of Giraffidae. Palaeontologia Electronica 19.3.50A: 1-39. https://doi.org/ $10.26879 / 653$ palaeo-electronica.org/content/2016/1702-the-metapodials-of-giraffidae

Ríos, M., Sánchez, I.M., and Morales, J. 2017. A new giraffid (Mammalia, Ruminantia, Pecora) from the late Miocene of Spain, and the evolution of the sivathere-samothere lineage. Plos One, 12(11):e0185378. https://doi.org/10.1371/journal.pone.0185378

Rodler A. and Weithofer K.A. 1890. Die Wiederkäuer der Fauna von Maragha. Denkschriften der Kaiserlichen Akademie der Wissenschaften Wien, 57:753-772.

Roussiakis, S. and Iliopoulos, G. 2004. Preliminary observations on the metrical variation of Helladotherium duvernoyi and Bohlinia attica. 5th International Symposium on Eastern Mediterranean Geology, Thessaloniki, p. 343-346.

Samson, P. and Radulesco, C. 1966. Sur la présence des Girafidés dans le Villafranchien supérieur de Roumanie. Neues Jahrbuch für Geologie und Paläontologie, Monatshefte, 10:588-594. 
Sánchez, I.M., Cantalapiedra, J.L., Ríos, M., Quiralte, V., and Morales, J. 2015. Systematics and evolution of the Miocene three-horned palaeomerycid ruminants (Mammalia, Cetartiodactyla). PloS One, 10(12):e0143034. https://doi.org/10.1371/journal.pone.0143034

Saraç, G. 2003. Turkiye Omurgali Fosil Yataklari. Mineral Res. Expl. Direct. Turkey (MTA), Scientific Report No: 10609, Ankara, Turkey. (In Turkish)

Schaller, O. 2007. Illustrated Veterinary Anatomical Nomenclature (second edition). Enke Verlag, Stuttgart, Germany. https://doi.org/10.1024/0036-7281.149.9.417c

Schlosser, M. 1924. Tertiary Vertebrates from Mongolia. Palaeontologia Sinica, Ser. C, 1.

Şenyürek, M.S. 1954. A study of the remains of Samotherium found at Taskınpasa. Ankara Universitesi Dil ve Tahir-Cografya Fakültesi Dergisi, 12(1-2):1-32. https://doi.org/10.1501/ dtcfder_0000001064

Solounias, N. 1981a. The Turolian fauna from the island of Samos, Greece, with special emphasis on the hyaenids and the bovids. Contributions to Vertebrate Evolution, 6:1-232. https://doi.org/10.1017/s0016756800026388

Solounias, N. 1981b. Mammalian fossils of Samos and Pikermi. Part 2. Resurrection of a classic Turolian fauna. Annals of Carnegie Museum, 50:231-270.

Solounias, N. 1988. Prevalence of ossicones in Giraffidae (Artiodactyla, Mammalia). Journal of Mammalogy, 69(4):845-848. https://doi.org/10.2307/1381645

Solounias, N. 2007. Family Giraffidae, p. 257-277. In Prothero, D.R. and Foss, S.E. (ed.), The Evolution of Artiodactyls. Johns Hopkins University Press, Baltimore.

Solounias, N. and Danowitz, M. 2016a. The Giraffidae of Maragheh and the identification of a new species of Honanotherium, p. 489-506. In Mirzaie Ataabadi, M. and Fortelius, M. (ed.), The Late Miocene Maragheh Mammal Fauna; Results of Recent Multidisciplinary Research, Palaeobiodiversity and Palaeoenvironments, 96(3). https://doi.org/10.1007/s12549-0160230-7

Solounias, N. and Danowitz, M. 2016b. Astragalar morphology of selected Giraffidae. PlosOne, 11(3):e0151310. https://doi.org/10.1371/journal.pone.0151310

Steininger, F. 1999. Chronostratigraphy, geochronology and biochronology of the Miocene "European land mammal mega-zones (ELMMZ)" and the Miocene "mammal zones (MNzones)", p. 9-24. In Rössner, G.E. and Heissig, K (ed.), The Miocene Land Mammals of Europe. Verlag Dr. Friedrich Pfeil, Munich.

Syrides, G.E. and Koliadimou, K.K. 1994. A new Pleistocene locality with continental mollusks and micro mammals in Strymon basin (Makedonia, Greece). Bulletin of the Geological Society of Greece, 30(1):331-339.

The NOW Community. 2016. New and Old Worlds Database of Fossil Mammals (NOW). Helsinki, Finland: University of Helsinki. Retrieved from http://www.helsinki.fi/science/now/

Toula, F. 1906. Das Gebiss und Reste der Nasenbeine von Rhinoceros (Ceratorhinus Osborn) hundsheimensis. Abhandlungen der k.k. Geologischen Reichsanstalt, Wien, 20(2):1-38.

Tranos, M.D. 2011. Strymon and Strymonikos Gulf basins (Northern Greece): implications on their formation and evolution from faulting. Journal of Geodynamics, 51(4):285-305. https:// doi.org/10.1016/j.jog.2010.10.002

Tranos, M.D., Kachev, V.N., and Mountrakis, D.M. 2008. Transtensional origin of the NE-SW Simitli basin along the Strouma (Strymon) Lineament, SW Bulgaria. Journal of the Geological Society, 165(2):499-510. https://doi.org/10.1144/0016-76492007-089

Tsoukala, E. 2018. Rhinocerotidae from the Late Miocene and Late Pliocene of Macedonia, Greece. A revision of the Neogene - Quaternary Rhinocerotidae of Greece. Revue de Paléobiologie, 37(2):609-630.

Vangengeim, E. and Tesakov, A. 2008. Maeotian Mammalian Localities of Eastern Paratethys: magnetochronology and position in European continental scales. Stratigraphy and Geological Correlation, 16(4):437-450. https://doi.org/10.1134/s0869593808040060

Vekua, A. and Lordkipanidze, D. 2008. The history of vertebrate fauna in Eastern Georgia. Bulletin of the Georgian National Academy of Sciences, 2(3):149-155.

Wagner, A. 1848. Urweltliche Säugthier-Ueberreste aus Griechenland. Abhandlungen der mathematisch-physikalischen Classe der Koeniglich-Bayerischen Akademie der Wissenschaften, 5(2):333-378.

Yilmaz, N.D. 2011. Batı Akdeniz Miyosen Dönem Giraffidae Buluntuları ve Anadolu İçin Önemi. Giraffidae remains of Miocene epoch of west Mediterrenean and their importance for Anatolia. Mehmet Akif Ersoy Üniversitesi Sosyal Bilimler Enstitüsü Dergisi, Yıl 3, Sayı, 4:113127. 
Zittel, K.A. 1893. Handbuch der Paläontologie. Vol. 4: Vertebrata (Mammalia). R. Oldenbourg, Munich and Leipzig, Germany. 
XAFIS ET AL.: GRIFFIDAE OF THERMOPIGI

\section{APPENDIX 1.}

Measurements of dental remains of Giraffidae from Thermopigi. Sin: left; Dex: right; L: length; I: width; min: minimum; max: maximum. All measurements are in millimetres $(\mathrm{mm})$.

\begin{tabular}{|c|c|c|c|c|c|c|c|c|c|c|c|c|c|c|c|c|}
\hline \multicolumn{17}{|c|}{ Deciduous dentition } \\
\hline Taxon & $\begin{array}{c}\text { Inv. } \\
\text { Number }\end{array}$ & $\operatorname{Sin} /$ Dex & LD2 & ID2 & LD3 & ID3 & LD4 & ID4 & & & & & & & & \\
\hline $\begin{array}{l}\text { Helladotherium } \\
\text { duvernoyi }\end{array}$ & SIT 1425 & $\sin$ & 36.07 & 23.02 & & & & & & & & & & & & \\
\hline $\begin{array}{l}\text { Helladotherium } \\
\text { duvernoyi }\end{array}$ & SIT 1260 & dex & & & & 27.75 & & & & & & & & & & \\
\hline Helladotherium & SIT 671 & $\sin$ & & & & & 40.36 & 39.89 & & & & & & & & \\
\hline \multicolumn{17}{|c|}{ Upper permanent dentition } \\
\hline Taxon & $\begin{array}{c}\text { Inv. } \\
\text { Number }\end{array}$ & Sin/Dex & P2-P4 & P2-M3 & LP2 & IP2 & LP3 & IP3 & LP4 & IP4 & LM1 & IM1 & LM2 & IM2 & LM3 & IM3 \\
\hline $\begin{array}{l}\text { Helladotherium } \\
\text { duvernoyi }\end{array}$ & SIT 1425 & $\sin$ & & & & & & & & & & & & & & \\
\hline $\begin{array}{l}\text { Helladotherium } \\
\text { duvernoyi }\end{array}$ & SIT 1001 & $\sin$ & & & 33.59 & 35.52 & & & & & & & & & & \\
\hline $\begin{array}{l}\text { Helladotherium } \\
\text { duvernoyi }\end{array}$ & SIT 1260 & dex & & & & & & & & & & & & & & \\
\hline $\begin{array}{l}\text { Helladotherium } \\
\text { duvernoyi }\end{array}$ & SIT 1251 & $\sin$ & & & & & 37.66 & 32.52 & & & & & & & & \\
\hline $\begin{array}{l}\text { Helladotherium } \\
\text { duvernoyi }\end{array}$ & SIT 671 & $\sin$ & & & & & & & & & & & & & & \\
\hline $\begin{array}{l}\text { Helladotherium } \\
\text { duvernoyi }\end{array}$ & SIT 1254 & dex & 113.79 & & 36.37 & 32.52 & 38.53 & 34.56 & 35.94 & 38.38 & 40.71 & 38.11 & 42.39 & 45.21 & & \\
\hline $\begin{array}{l}\text { Helladotherium } \\
\text { duvernoyi }\end{array}$ & SIT 651 & $\sin$ & & & & & & & 33.99 & 41.76 & & & & & & \\
\hline $\begin{array}{l}\text { Palaeotragus } \\
\text { rouenii }\end{array}$ & SIT 1253 & $\sin$ & 49.34 & 122.8 & 14.38 & 18.43 & 16.34 & 20.3 & 18.6 & 22.45 & 24.02 & 26.6 & 26.26 & 28.7 & & \\
\hline $\begin{array}{l}\text { Palaeotragus } \\
\text { rouenii }\end{array}$ & SIT 1153 & $\sin$ & & & & & & & & & & & & & 23.18 & 26.1 \\
\hline $\begin{array}{l}\text { Palaeotragus } \\
\text { sp. }\end{array}$ & SIT 1511 & $\sin$ & 54.26 & & 20.71 & 15.64 & 18.54 & 18.16 & 17.76 & 20.26 & & & & & & \\
\hline \multicolumn{17}{|c|}{ Lower permanent dentition } \\
\hline \multicolumn{17}{|c|}{ Incisors } \\
\hline Taxon & $\begin{array}{c}\text { Inv. } \\
\text { Number }\end{array}$ & $\operatorname{Sin} /$ Dex & LI3 & II3 & LC & Icmax & Icmin & & & & & & & & & \\
\hline $\begin{array}{l}\text { Palaeotragus } \\
\text { rouenii }\end{array}$ & SIT 1252 & dex & & & 13.87 & 16.23 & 11.9 & & & & & & & & & \\
\hline $\begin{array}{l}\text { Palaeotragus } \\
\text { sp. }\end{array}$ & SIT 1119 & dex & 12.77 & 16.72 & & & & & & & & & & & & \\
\hline \multicolumn{17}{|c|}{ Premolars and molars } \\
\hline Taxon & $\begin{array}{c}\text { Inv. } \\
\text { Number }\end{array}$ & Sin/Dex & P2-P4 & P2-M3 & LP2 & IP2 & LP3 & IP3 & LP4 & IP4 & LM1 & IM1 & LM2 & IM2 & LM3 & IM3 \\
\hline $\begin{array}{l}\text { Palaeotragus } \\
\text { sp. }\end{array}$ & SIT 700 & $\sin$ & 58.83 & 140.97 & 17.6 & 9.6 & 19.99 & 12.43 & 21.66 & 13.61 & 23.85 & 15.56 & 24 & 15.99 & 35.39 & 15.9 \\
\hline $\begin{array}{l}\text { Helladotherium } \\
\text { duvernoyi }\end{array}$ & SIT 1429 & dex & & & & & & & & & 48.77 & 32.75 & & & & \\
\hline
\end{tabular}




\section{APPENDIX 2.}

Measurements of post-cranial elements of the front limb of Giraffidae from Thermopigi. Sin: left; Dex: right; L: length; I: width; APD: antero-posterior diameter; TD: transverse diameter; prox: proximal; dia: diaphysis; dis: distal; t.s.: tuberculum supraglenoidale; g.c.: glenoid cavity; neck: neck of scapula (collum scapulae); r: radius; r-u: radius-ulna; $\mathrm{H}$ : maximum height of magnumcapitatum; h: minimum height of magnum-capitatum. All measurements are in millimetres $(\mathrm{mm})$.

\begin{tabular}{|c|c|c|c|c|c|c|c|c|c|c|}
\hline & & & & apula & & & & & & \\
\hline Taxon & $\begin{array}{c}\text { Inv. } \\
\text { Number }\end{array}$ & Sin/Dex & $\begin{array}{l}\text { APD } \\
\text { prox }\end{array}$ & TDt.s. & $\begin{array}{l}\text { APD } \\
\text { g.c. }\end{array}$ & $\begin{array}{l}\text { TD } \\
\text { g.c. }\end{array}$ & $\begin{array}{l}\text { APD } \\
\text { neck }\end{array}$ & $\begin{array}{c}\text { TD } \\
\text { neck }\end{array}$ & & \\
\hline $\begin{array}{l}\text { Helladotherium } \\
\text { duvernoyi }\end{array}$ & SIT 1034 & dex & 170.2 & 167.9 & 108.6 & 124.3 & 108.6 & 62 & & \\
\hline \multirow{3}{*}{$\begin{array}{l}\text { Samotherium } \\
\text { major }\end{array}$} & SIT 922 & $\sin$ & 161.5 & 81 & 85 & 106 & 101.4 & 29.2 & & \\
\hline & \multicolumn{6}{|c|}{ Humerus } & & & & \\
\hline & $\begin{array}{c}\text { Inv. } \\
\text { Number }\end{array}$ & Sin/Dex & $\begin{array}{l}\text { APD } \\
\text { dia }\end{array}$ & $\begin{array}{l}\text { TD } \\
\text { dia }\end{array}$ & APDdis & TDdis & & & & \\
\hline $\begin{array}{l}\text { Helladotherium } \\
\text { duvernoyi }\end{array}$ & SIT 306 & dex & 72.5 & 74.2 & 116.86 & 159.42 & & & & \\
\hline $\begin{array}{l}\text { Helladotherium } \\
\text { duvernoyi }\end{array}$ & SIT 318 & dex & 98.54 & 86.05 & 119.83 & 168.76 & & & & \\
\hline $\begin{array}{l}\text { Palaeotragus } \\
\text { rouenii }\end{array}$ & SIT 939 & dex & 53.08 & 38.71 & 77.32 & 78.08 & & & & \\
\hline \multirow[t]{2}{*}{$\begin{array}{l}\text { Samotherium } \\
\text { major }\end{array}$} & SIT 313 & $\sin$ & 68.73 & 68.24 & & 124.26 & & & & \\
\hline & \multicolumn{7}{|c|}{ Radius-Ulna } & \multirow[b]{2}{*}{ TDdia } & \multirow[b]{2}{*}{ APDdis } & \multirow[b]{2}{*}{ TDdis } \\
\hline Taxon & $\begin{array}{c}\text { Inv. } \\
\text { Number }\end{array}$ & Sin/Dex & Lr & Lr-u & $\begin{array}{l}\text { APD } \\
\text { prox }\end{array}$ & $\begin{array}{l}\text { TD } \\
\text { prox }\end{array}$ & $\begin{array}{l}\text { APD } \\
\text { dia }\end{array}$ & & & \\
\hline $\begin{array}{l}\text { Helladotherium } \\
\text { duvernoyi }\end{array}$ & SIT 319 & $\sin$ & & & 96.64 & 157.71 & 77.1 & 110.02 & & \\
\hline $\begin{array}{l}\text { Helladotherium } \\
\text { duvernoyi }\end{array}$ & SIT 937 & $\sin$ & & & 74.9 & 149.76 & 52.5 & 88.26 & 68.26 & 133.37 \\
\hline $\begin{array}{l}\text { Palaeotragus } \\
\text { rouenii }\end{array}$ & SIT 1256 & dex & 568 & & 44.53 & 83.21 & 34.47 & 46.36 & 51.51 & 67.7 \\
\hline $\begin{array}{l}\text { Samotherium } \\
\text { major }\end{array}$ & SIT 312 & $\sin$ & 675 & 780 & 74.49 & 126.11 & 51.61 & 70.76 & 80.8 & 101.69 \\
\hline $\begin{array}{l}\text { Samotherium } \\
\text { major }\end{array}$ & SIT 1020 & $\sin$ & 615 & 760 & 86.74 & 135.92 & & & & \\
\hline $\begin{array}{l}\text { Samotherium } \\
\text { major }\end{array}$ & SIT 1352 & $\sin$ & & & 66.29 & 133.14 & & & & \\
\hline
\end{tabular}

\begin{tabular}{lcccccc}
\multicolumn{7}{c}{ Magnum-capitatum } \\
\multicolumn{1}{c}{ Taxon } & Number & Sin/Dex & L & I & H & h \\
\hline $\begin{array}{l}\text { Helladotherium } \\
\text { duvernoyi }\end{array}$ & SIT 542 & $\operatorname{dex}$ & 77.26 & 58.43 & 37 & 26.8 \\
\end{tabular}

\begin{tabular}{|c|c|c|c|c|c|c|c|c|c|c|}
\hline \multicolumn{11}{|c|}{ Metacarpus } \\
\hline Taxon & $\begin{array}{c}\text { Inv. } \\
\text { Number }\end{array}$ & Sin/Dex & L & $\begin{array}{l}\text { APD } \\
\text { prox }\end{array}$ & $\begin{array}{l}\text { TD } \\
\text { prox }\end{array}$ & $\begin{array}{c}\text { APD } \\
\text { dia }\end{array}$ & TDdia & APDdis & TDdis & $\begin{array}{l}\text { TDprox/ } \\
\text { APDprox }\end{array}$ \\
\hline $\begin{array}{l}\text { Helladotherium } \\
\text { duvernoyi }\end{array}$ & SIT 863 & dex & & & & 52.15 & 76.79 & & & \\
\hline $\begin{array}{l}\text { Helladotherium } \\
\text { duvernoyi }\end{array}$ & SIT 1043 & $\sin$ & 463.79 & 76.2 & 129.26 & 63.49 & 77.7 & 67.19 & 116.22 & 1.7 \\
\hline
\end{tabular}


XAFIS ET AL.: GRIFFIDAE OF THERMOPIGI

\begin{tabular}{|c|c|c|c|c|c|c|c|c|c|c|}
\hline $\begin{array}{l}\text { Helladotherium } \\
\text { duvernoyi }\end{array}$ & SIT 920 & dex & 455.79 & 63.88 & 102.87 & 47.41 & 59.32 & 59.78 & 99.02 & 1.61 \\
\hline $\begin{array}{l}\text { Helladotherium } \\
\text { duvernoyi }\end{array}$ & SIT 300 & $\sin$ & & & & & & 56.94 & 101.08 & \\
\hline $\begin{array}{l}\text { Helladotherium } \\
\text { duvernoyi }\end{array}$ & SIT 1254 & $\sin$ & 462.79 & 60.82 & 104.64 & 51.43 & 65.31 & 55.22 & 96.39 & 1.72 \\
\hline $\begin{array}{l}\text { Palaeotragus } \\
\text { rouenii }\end{array}$ & SIT 303 & dex & & & & 32.3 & 33.91 & 35.88 & 56.03 & \\
\hline $\begin{array}{l}\text { Palaeotragus } \\
\text { rouenii }\end{array}$ & SIT 302 & $\sin$ & 475.79 & 42.93 & 64.44 & 35.46 & 34.64 & 38.45 & 64.96 & 1.50 \\
\hline $\begin{array}{l}\text { Palaeotragus } \\
\text { rouenii }\end{array}$ & SIT 431 & dex & & & & & & 37.35 & 55.05 & \\
\hline $\begin{array}{l}\text { Palaeotragus } \\
\text { rouenii }\end{array}$ & SIT 309 & $\sin$ & & 44.79 & & 34.8 & 31.26 & & & \\
\hline $\begin{array}{l}\text { Samotherium } \\
\text { major }\end{array}$ & SIT 314 & dex & 485.79 & 64.34 & 100.17 & 42.57 & 58.16 & 57.46 & 96.16 & 1.56 \\
\hline
\end{tabular}




\section{APPENDIX 3.}

Measurements of post-cranial elements of the hind limb of Giraffidae from Thermopigi. Sin: left; Dex: right; L: length; APD: antero-posterior diameter; TD: transverse diameter; prox: proximal; dia: diaphysis; dis: distal; $\mathrm{H}$ : height; lat: lateral; med: medial; Hmax: maximum height; Hmin: distance between the sustentaculum tali and the tuber calcanei; tuber: tuber calcanei; H1: Height of the cubonavicular on the level of the medial astragalar surface; H2: Height of the cubonavicular on the level of the lateral astragalar surface. All measurements are in millimetres $(\mathrm{mm})$.

\begin{tabular}{|c|c|c|c|c|c|c|c|c|}
\hline \multicolumn{9}{|c|}{ Tibia } \\
\hline Taxon & $\begin{array}{c}\text { Inv. } \\
\text { Number }\end{array}$ & Sin/Dex & $\begin{array}{l}\text { APD } \\
\text { prox }\end{array}$ & TDprox & APDdia & TDdia & APDdis & TDdis \\
\hline $\begin{array}{l}\text { Helladotherium } \\
\text { duvernoyi }\end{array}$ & SIT 1255 & dex & & & 56.95 & 83.97 & 90.3 & 120 \\
\hline $\begin{array}{l}\text { Helladotherium } \\
\text { duvernoyi }\end{array}$ & SIT 316 & $\sin$ & & & 56 & 84.47 & 88.1 & 124 \\
\hline $\begin{array}{l}\text { Helladotherium } \\
\text { duvernoyi }\end{array}$ & SIT 992 & dex & & & & & 90.18 & 123.05 \\
\hline Helladotherium & SIT 317 & $\sin$ & 121.63 & 166.51 & 64.05 & 82.79 & & \\
\hline & & Malleolus & & & & & & \\
\hline Taxon & $\begin{array}{l}\text { Inv. } \\
\text { Number }\end{array}$ & Sin/Dex & APD & TD & H & & & \\
\hline $\begin{array}{l}\text { Helladotherium } \\
\text { duvernoyi }\end{array}$ & SIT 992 & dex & 75.13 & & 39.65 & & & \\
\hline $\begin{array}{l}\text { Helladotherium } \\
\text { duvernoyi }\end{array}$ & SIT 1002 & $\sin$ & 78.66 & 38.02 & 43.47 & & & \\
\hline \multicolumn{9}{|c|}{ Astragalus } \\
\hline Taxon & $\begin{array}{l}\text { Inv. } \\
\text { Number }\end{array}$ & Sin/Dex & Llat & Lmed & APDprox & Tdprox & APDdis & TDdis \\
\hline $\begin{array}{l}\text { Helladotherium } \\
\text { duvernoyi }\end{array}$ & SIT 1005 & $\sin$ & 124.2 & 110.54 & 64.08 & 76.13 & 60.45 & 81.17 \\
\hline $\begin{array}{l}\text { Helladotherium } \\
\text { duvernoyi }\end{array}$ & SIT 1109 & $\sin$ & & 111.11 & & & 47.26 & 68.83 \\
\hline \multicolumn{9}{|c|}{ Calcaneus } \\
\hline Taxon & $\begin{array}{l}\text { Inv. } \\
\text { Number }\end{array}$ & Sin/Dex & Hmax & Hmin & APDmax & TDmax & APDtuber & TDtuber \\
\hline $\begin{array}{l}\text { Helladotherium } \\
\text { duvernoyi }\end{array}$ & SIT 315 & $\sin$ & 245.04 & 164.74 & 100.91 & 70.07 & 55.67 & \\
\hline $\begin{array}{l}\text { Helladotherium } \\
\text { duvernoyi }\end{array}$ & SIT 1004 & $\sin$ & & & 107.55 & 79.1 & & \\
\hline \multicolumn{9}{|c|}{ Cubonavicular } \\
\hline Taxon & $\begin{array}{l}\text { Inv. } \\
\text { Number }\end{array}$ & Sin/Dex & Hmax & APDmed & APDmax & TD & H1 & $\mathrm{H} 2$ \\
\hline $\begin{array}{l}\text { Helladotherium } \\
\text { duvernoyi }\end{array}$ & SIT 1059 & $\sin$ & 77.32 & 92.69 & 105.46 & 100.92 & 31.25 & 39.55 \\
\hline \multicolumn{9}{|c|}{ Metatarsus } \\
\hline Taxon & $\begin{array}{l}\text { Inv. } \\
\text { Number }\end{array}$ & Sin/Dex & $\mathbf{L}$ & APDprox & TDprox & APDdia & TDdia & TDprox/APDprox \\
\hline $\begin{array}{l}\text { Helladotherium } \\
\text { duvernoyi }\end{array}$ & SIT 301 & dex & & 84.61 & 88.83 & 59.74 & 56.83 & 1.05 \\
\hline $\begin{array}{l}\text { Helladotherium } \\
\text { duvernoyi }\end{array}$ & SIT 938 & $\sin$ & & 106.18 & 103.72 & 66.19 & 55.49 & 0.98 \\
\hline $\begin{array}{l}\text { Palaeotragus } \\
\text { rouenii }\end{array}$ & SIT 307 & $\sin$ & 497.79 & & 47.14 & 29.54 & 30.53 & \\
\hline
\end{tabular}


XAFIS ET AL.: GRIfFIDAE OF THERMOPIGI
Palaeotragus
SIT 970
dex
53.17
41.02
32.22

rouenii

\section{Proximal Phalanx}

\begin{tabular}{|c|c|c|c|c|c|c|c|}
\hline Taxon & Number & Sin/Dex & $\mathbf{L}$ & APDprox & TDprox & APDdis & TDdis \\
\hline $\begin{array}{l}\text { Helladotherium } \\
\text { duvernoyi }\end{array}$ & SIT 1250 & dex & 107.56 & & 54.35 & 32.61 & 50.57 \\
\hline Samotherium major & SIT 310 & dex & 120.95 & 51.38 & 48.68 & 32.5 & 42.6 \\
\hline Samotherium major & SIT 311 & $\sin$ & & 47.5 & 50.28 & 34.43 & 36.9 \\
\hline \multicolumn{6}{|c|}{ Distal Phalanx } & & \\
\hline Taxon & $\begin{array}{c}\text { Inv. } \\
\text { Number }\end{array}$ & Locality & Sin/Dex & $\mathbf{L}$ & $\mathbf{H}$ & & \\
\hline $\begin{array}{l}\text { Helladotherium } \\
\text { duvernoyi }\end{array}$ & SIT 541 & Thermopigi & dex & 101.29 & 57.3 & & \\
\hline
\end{tabular}

